\title{
UEBER DIE ANFAENGE DES BLANKVERSES IN ENGLAND.
}

I.

Die eingehende philologische beschăftigung mit Shakspere hat notweudigerweise auch das gebiet der metrik berthren mllssen, und eine nicht kleine literatur hat sich denn auch daruber schon angesammelt. Von Deutschen forschungen ist insbesondere der excurs uber Shakspere's versbau von Tycho Mommsen in den Prolegomena zu seiner aukgabe von 'Romeo und Julie' hervorzuheben.' In ähnlicher weise bistorisch zurlickgreifend, hat Jacob Schipper den vers Marlowe's untersucht und damit den blankvers in seinem ersten auftreten auf der 8 ffentlichen buhne in England charakterisiert.2

Beide forscher behandeln im wesentlichen nur den versrythmus und die silbenmessung: A bbott in seiner 'Shakespearean Grammar' berthrt auch die wortbetonung. Die vorhergehenden metrischen zustände werden nicht mit in den bereich ihrer untersuchungen gezogen.

Obwol nun auf dem gebiete der Englischen metrik im allgemeinen noch die grundlegenden arbeiten fehlen, erscheint es doch vorläufig wunschenswert, fur den so viel behandelten Shakspere'schen blankvers die historische grundlinie zu ziehen. Denn wenn auch von Marlowe's 'Tamburlaine the Great' im jahre 1587 die fast alleinige herschaft dieses verses in den dramen der folgezeit abzuleiten ist, so ist derselbe doch ein

'Shakespeare's 'Romeo und Julis' hg. von 'T. Mommsen, Oldenburg 1859.

2 J. Schipper, de versu Marlovii. Bonner doctordissert., 1867.

Anglia, 1V. band. 
kind der vorhergehenden leistungen in der art, und durch diese zu erklären. Auch findet man nicht selten gelegentliche bemerkungen über die handhabung des blankverses vor den grossen dramatikern, die sich auf keinerlei diesbezügliche untersuchungen stützen. Nach dessen betrachtung wird sich vielleicht manches einfacher und von bestimmten gesichtspunkten aus behandeln lassen.

Vorliegende arbeit hat sich daher die aufgabe gestellt, den Englischen blankvers von seinem ersten auftreten an bis auf Marlowe zu verfolgen.

Es ist vor allem wichtig, dass der blankvers in England sich zuerst bei Surrey findet, einem dichter, den ich chronologisch als den ersten Neuenglischen dichter bezeichnen möchte. Es steht die einführung des blankverses somit im zusammenhange mit dem auflebęn der neuen kunstpoesie in der ersten hälfte des 16. jh., deren chorfuhrer vor allen andern Surrey ist. Sein blankvers ist demnach auch nur im zusammenhange mit seinen ubrigen dichtungen zu betrachten.

Der funffussige jambus wurde von Chaucer in England eingeburgert.1 Dass diese bezeichnung ebensowenig für den Englischen wie für den Deutschen funftactigen aufsteigenden rhythmus passt, ist bekannt; aus praktischen grlinden wird sie aber doch beizubehalten sein, sowie die graphische darstellung nach art der antiken metrik.

Der Italienische endecasillabo ist das vorbild, doch bei der verschiedenartigkeit der Romanischen und Germanischen sprachen muste auch der vers sich im Englischen anders gestalten. Während wir im Italienischen endecasillabo blos gewisse feste punkte haben, zeigt Chaucer das entschiedene bestreben, regelmässig auf senkung, hebung folgen zu lassen. Wie sehr der jambische rhythmus - um nun den ausdruck beizubehalten - der Englischen wie der Deutschen sprache angemessen ist, wurde schon oftmals hervorgehoben. Die weiterentwicklung des verses in England spricht am deutlichston dafur.

1 Das vorkommen des verses in England in viel frtherer zeit hat J. Schipper in Wien in seinen vorlesungen über Englische metrik im W. S. $1879 ; 80$ nachgewiesen. 
Besondere umstïnde, vor allem die, dass die Englische sprache zu Chaucer's zeit noch nicht als einheitliche schriftsprache sich consolidiert batte und dass die Englische literatur im 15. jh. nicht entfernt mit dem aufschwung des 16. jh. zu vergleichen ist, lassen das verdienst Chaucer's in metrischer hinsicht nicht hinreichend zu tage treten. Erst Surrey war es in der ersten hälfte des 16. jh. vergönnt, von epochemachendem einfluss auf die formvollendung der Englischen kunstdichtung zu werden.

Wirkte einerseits das silbenzählende Romanische prinzip gewissermassen reinigend auf die etwas ungehobelte metrik der Mittelengl. periode, so war das Germanische prinzip andrerseits mit seiner begünstigung der hebungen und der tonwerte der einzelnen wörter hemmend auf den fluss des verses. Der theoretisch als erste senkung zu bezeichnende, schlechte taktteil des ersten taktes ward hie und da als auftakt weggelassen, desgleichen senkungen im innern des verses $u$. dgl. $\mathrm{m}$. Dabei sind aber auch die schwankenden betonungen und tonwerte der einzelnen wörter nicht aus den augen zu lassen. Als dritter faktor kommt gewis die neigung zu regelmässiger jambischer scansion innerhalb der festen silbenzahl, ohne rlicksicht auf die betonungen, in rechnung.

Wenn nun anch im laufe der entwick Tung der fünffassige jambus sich der daraus hervorgehenden hărten entledigt und bereits in der uns hier beschäftigenden periode die widersprechenden prinzipien, in regelmässig rhythmischer silbenzählung mit berïcksichtigung der betonungen vereinigt, sollte dennoch die historische betrachtung von Chaucer ausgehen.

Eine philologische behandlung von Chaucer's metrik wird wol allgemein als ein grosses bedürfnis gefuhlt; sie fehlt leider bis heute, obwol uns fur den zweiten teil der Chaucerstudien von Bernhard ten Brink eine solche in aussicht steht. Auf dieser noch mangelnden basis wäre dann die weiterentwicklung bis zur Neuengl. periode klar zu legen. Bis dahin kann die metrik also nur provisorisch für einzelne denkmäler in dieser versgattung betrachtet werden, und ich werde mich bei dem dichter Surrey, den ich als ausgangspunkt meiner untersuchung aufstelle, nur auf die darlegung des tatsächlichen beschränken müissen. 
Es würde den rahmen dieser abhandlung tuberschreiten, das verhältnis Surrey's zu seinen unmittelbaren vorgängern zu characterisieren, zumal da die bemerkenswerten erscheinungen bei seinen nachfolgern im blankverse bei ihm ihre genugende erklärung finden. Ich gedenke ein anderes mal die resultate meiner diesbeztiglichen. untersuchungen vorzulegen.1

Interessant ist es hinsichtlich der theorie der Englischen metrik die zeitgenössischen aussprüche heranzuziehen.

Vor allen andern sind zu erwähnen die 'Certayne notes of Instruction concerning the making of verse or ryme in English' von George Gascoigne, zuerst erschienen 1575; ferner William Webbe's 'Discourse of English Poetrie' 1586, George Puttenham's 'Arte of English Poesie' 1589 und Sir Philip Sydney's 'Apologie for Poetrie' 1595, sämtlich erschienen in Arber's vortrefflichen Reprints, ersteres in einem heftchen mit 'The Steele Glas' und 'The complaynt of Philomene', wonach ich citiere.

Von Gascoigne's 'Notes' habe ich höchst willkommenen gebrauch gemacht, insonderheit als dieselben meines wissens zuerst schwarz auf weiss bezeugen, dass jambischer rhythmus mit bewustsein angewendet ist. Ich komme darauf wiederholt noch unten zurlick.

Was die andren schriften anbelangt, so kann ich das nicht von ihnen sagen. Im gegenteil glaube ich in Webbe und Puttenham blosse theoretiker zu erkennen, die entschieden das wesen der Englischen sprache und poesie verkannt haben. Lateinische rythmen und prosodie den Englischen versen aufzudrängen war ein verungluckter versuch, wie man an Webbe's eigenen leistungen sehen kann. Sagt letzterer doch ganz deutlich a. a. 0. 8. 70: 'and in truetb I did rather alwaies omitt the best wordes and such as would naturally become the speech best, then I wolde comitte any thing, which

- Es sei nur vorläufig angedentet, dass es für mich feststeht, dass fiir den Englischen vers im anfange des 16. jhs. dieselbe scandierende (nicht etwa blos silbenzïhlende) versmessung ohne rücksicht anf die wortbetonung zu gelten hat, die u. a. E. Hopfner für den Deutschen vers dieser und der etwas späteren zeit erwiesen hat. S. Reformbestrebungen auf dem gebiete der Deutschen dichtung des 16. und 17. jh. Programm des k. Wilhelms-gymnasiuns zu Berlin 1966, s. 5. 
shoulde notoriously impugne the Latine rules, which herein I had onely for any direction'.

Zudem standen Webbe, Puttenham und Sydney den bahnbrechern der neuen kunstpoesie schon ferner, und ihre belehrung können wir umsomehr entbehren, als wir durch Gascoigne, der als dichter setbst mitten im strome steht, liber das, was wir wissen wollen, aufschluss erhalten.

Ich gehe an die aufzählung der einzelnen quellen.

Henry Howard, Earl of Surrey ${ }^{1}$, geboren 1516?, enthauptet 1547, übertrug das $z$ weite und vierte buch von Virgils Aeneide, vermutlich in seinen reiferen jahren, in Englische blankverse. Es sind dies die ersten, die in England geschrieben wurden, soviel man bis jetzt weiss. Er hatte in seinen tubrigen dichtungen durchweg jambischen rhythmus und sebr häufig den jambischen zebnsilbler angewendet. Seiner ubersetzung lag die von Gawin Douglas, in paarweise gereimten, fünfussigen jamben vor. Eine directe beeinflussung durch die Italienische übersetzung ${ }^{2}$ des cardinals Ippolito de Medici oder Francesco Maria Molza's, wie Morley (First sketch of E. lit. $294 \mathrm{f}$.) will, ist wol nicht nötig anzunehmen, obwol es möglich ist, dass der Italienische blankvers Surrey zur nachahmung gereizt hatte. Es scheint mir eher wahrscheinlich, dass Surrey selbst darauf verfallen sei, sowie er sich auch einmal im reimlosen alexandriner versuchte, wenn auch mit weniger erfolg.

Wie sehr Surrey's tat bei seinen zeitgenossen anklang fand, ist aus eiver stelle in Ascham's 'Schoolemaster' ersichtlich, die Warton Hist. of E. P. IV. 38, anfuhrt. Freilich scheint man später wieder darauf vergessen zu haben, und Surrey's 'Songs and Sonnets' spielen eine weit grössere rolle. Der umstand, dass die ubersetzung einige tage später als die zunächst zu besprechenden blankverse im druck erschien (vgl. die einleitung zu Arber's reprint von Tottel's 'Miscellany' s. XI), ist nichtssagend.

1 Ein grösseres Englisches werk uber Wiat und Surrey von dr. Nott ist mir leider weder in Strassburg noch in Wien erreichbar gewesen.

2 Uebrigens sei bemerkt, dass Tiraboschi, Stor. de lett. it. VII, 32, 1657, nur von einer übersetzung des zweiten buches der Aeneide spricht. 
In Tottel's 'Miscellany' 1557 finden wir schon einen nachfolger im blankvers. Es ist Nicholas Grimoald mit seinen zwei gedichten: "The death of Zoroas, an Egiptian Astronomer, in first fight, that Alexander had with the Persians' und 'Marcus 'T'ullius Ciceroes death'.

3. Bald darauf erschien das erste drama in blankversen, zugleich die erste regelrechte tragödie, 'Gorboduc' von Sackville und Norton, 1561; ihm folgte 1566 .4. 'Jocasta' von Gascoigne und Francis Kinwelmarshe.

5. In das jahr 1567 fallen blankverse von George Turbervile." In "The heroycall epistles of the Learned Poet Publius Ovidius Naso, in Englishe verse, set out and translated by George 'Turbervile Gent. with Aulus Sabinus Aunsweres to certaine of the same, ann. dom. 1567' sind 6 episteln und zwar 'Canace to Machareus, Medea to Jason, Laodameia to Protesilaus, Hypermenestra to Lynceus, Acontius to Cydippe und Cydippe to Acontius' in blankrersen abgefasst.

6. Mit diesen versuchen vielleicht in zusammenhang stehen die zwei jahre später in van der Noodt's 'Theatre for worldings' erschienenen 15 sonnetten Spenser's, die man als frühere fassungen der 'Visions of Bellay' erkannt hat.

Dazwischen fiele für das jahr 1568 ein blankversdrama 'Tancred and Gismonda', doch dies ward erst später in blankverse umgeschrieben, urspringlich in reimen abgefasst. Collier in seiner 'Hist. of Dram. L.' und der herausgeber des stückes in Dodsley's 'Collection' geben fur die neuherausgabe, die mit der

- Einer von bischof Percy 1808 unternommenen, aber bis auf vier exemplare verbrannten ausgabe von nichtdramatischen blankversgedichten vor Milton's Paradise lost (s. Collier, Bibliogr. a. critic. account of the rarest books in the Engl. lang. II, 408) sind folgende hierher gehorige daten zu entnehmen:

1567 George Turbervile, 6 episteln in blankvers. 1576 Gascoigne's

Steele Glas. 1584 Precepts for a state by Barnabie Riche. 1585

Blank verses by George Peele, The moores adress to the Lord Major of London. The epistle of Pontius Pilate by J. Higgins, from the Mirror of Magistrates.

Ueber das letzte denkmal ist es mir trotz der gitigen nachforschungen moines freundes, dr. Brandl in London, nicht gelungen, etwas in erfahrung 20 bringen. 
bemerkung 'newly revised and polisher according to the decorum of these days' versehen war, das jabr 1591 an. Auch spricht dieser besondere zusatz für eine zeit, wo der blankvers also schon als tonangebend betrachtet wurde, was ror Marlowe nicht der fall war. Da Ward a. a. o. I. 117, die angaben seiner rorgänger nicht widerlegt, sondern stillschweigend das jahr 1572 ansetzt, berubt dies vielleicht auf einem versehen.

7. Im jahre 1576 erschien die erste grössere, nicht dramatische blankversdichtung nach Surrey's Virgilubertragung: George Gascoigne's 'Steele Glas', nachdem der dichter ein jahr vorher sich des nähern uber die theorie der Englischen dichtkunst verbreitet hatte in der unten wiederholt angefuhiten abbandlung.

8. Für das jahr 1584 finden sich blankverse in einem gedichte von 170 versen, in "The second Tome of the travailes and adrentures of Don Simonides, enterlaced with varietie of Historie, wherein the curteous and not curious Reader maie finde matters so leveled as maie suffice to please all humours. Written by Barnabe Rich, gentl.' London 1584 (s. Collier Bibl. a. crit. acc. II $246 \mathrm{f}$ ).

9. Nach Ward's anuahme fällt die abfassung von Lyly's 'The Woman in the Moone' ebenfalls in das jahr 1584. Es ist wegen der mit prosa untermischten verwendung des blankverses interessant.

10. In dasselbe jahr fällt Peele's festspiel 'T'be Arraignment of Paris', wichtig durch die anwendung des blankverses in einzclnen, sich aus dem ganzen besonders abhebenden monologen. Von demselben dichter besitzen wir ein blankversgedichtchen aus etwas friherer zeit, die 'Lines addressed to 'Thomas Watson', die dessen 'Hekatompathia' (1582) vorangesetzt wurden. In das jahr 1585 fällt die einleitende rede in blankversen zu seinem 'Device of the pageant before Wolstan Dixi'.

11. Von Robert Greene finden sich fur das jahr 1587 blankverse in 'The description of Silvestro's Lady', aus seinem 'Morando, the Tritameron of Love', 1587.

12. Als letztes denkmal vielleicht vor dem entscheidenden schritt, den Marlowe's 'lamburlaine uber die öffentliche bụhne 
machte, findet sich noch ein drama in blankrersen, "The Misfortunes of Arthur' von Thomas Hughes u. a., aufgefthrt den 8. Febr. 1587. Freilich ist es - was auch Collier, Hist. of Dram. L. III 41 bemerkt - möglich, dass Marlowe's Tamburlaine bereits ther die buhne gegangen war, und somit nicht Hughes Marlowe's, sondern Marlowe Hughes' vorbild gewesen. Doch da tuber die auffuhrung des Tamburlaine kein datum vorliegt, ziehe ich die 'Misfortunes of Arthur' mit in den bereich meiner untersuchung.

'The Famous Victories of Henry the Fifth', nach Ward vor 1588 aufgefuhrt, gehören nicht hierher. Das stluck ist, wie schon Collier a. a. 0. III 108 bemerkt, in prosa abgefasst und nur so gedruckt, dass es fltichtig besehen, als in reimlosen versen abgefasst erscheinen mag.

Freilich kann es leicht möglich sein, und gewis ist dies sogar sehr wahrscheinlich, dass noch mancher blankvers in der zeit geschrieben ward, dem auf die spur zu kommen mir hier leider nicht möglich ist. Doch glaube ich dass ein werk, das für die entwicklung der Englischen dichtkunst von einfluss gewesen, jedenfalls augenfälligere spuren hinterlassen haben mutste. Wenn dies nicht der fall, hat dessen aufzähling nur bibliographischen wert. Ich denke auch von den versuchen der königin Elisabeth, die Warton, H. of $E$. P. IV 280, nach 1561 ansetzt, umgang nehmen zu können, zumal da dieselben nur handschriftlich vorhanden, und Warton devon sagt: 'it has, however, no other recommendation but its royalty'.

Jedenfalls spielt der blankvers die ganze zeit bindurch, wenn auch eine gute, so doch eine sehr kleine rolle. Die lyrischen, epischen, didaktischen dichtungen der zeit sind meist in gereimten funffussigen jamben, in gereimten alexandrinern und in gereimten siebenfüssigen jamben, sehr bäufig auch in der verbindung der beiden letztgenannten versarten geschrieben und gelangen darin $\mathrm{zu}$ nicht geringer formvollendung.

Die dramen der zeit fallen vor allem durch die oft ganz willkurliche untereinandermischung obengenannter versformen auf. Am rucksichtslosesten wird mit wortbetonung und silbenzahl geschaltet, daneben das unachtsame tabergehen von einem rhythmus in den andern, das nicht mehr als gelegentliches versęhen angesehen werden kann. Dabei macht sich jenes 
eigentlimliche versmass, das noch nicht năher untersucht ist', und das im wesentlichen aus vier takten aufsteigenden rhythmus, am häufigsten aus der doppelten setzung je eines jambus und anapästrs besteht, fast uberall geltend. Es finden sich darin all die freiheiten der Mengl. metrik nach German. prinzipien, fehlen einzelner senkungen, des auftaktes $\mathbf{u}$. dgl. $\mathbf{m}$. Obwol zuweilen in prologen und monologen der gereimte funffissige jambus mit absicht verwendet zu sein scheint, und uberhaupt besonders in der zweiten bälfte des jahrhunderts häufig metrisch ganz glucklich gebaute partieen vorkommen, kann man doch kein einheitliches princip erkennen. Das, wodurch sich die blankversstücke durchweg von den andern dramen der zeit unterscheiden, ist das regelrechte einhalten desselben rythmus; und damit fuhren sie unleugbar zu dem versbau Marlowe's und der andern grossen dramatiker hinuber.

\section{II.}

Ich wende mich nun zu den einzelnen denkmälern und beginne mit Surrey, bei dem auch seine ubrigen dichtungen, soweit sie zur beleuchtung seines blankverses dienlich sind, herangezogen werden mulssen. Von der qualităt der reime sehe ich naturlich hier ab.

Bei der besprechung von Surrey's metrik kommen drei gesichtspunkte in betracht, die behandlung der silbenmessung der einzelnen wörter, der wortbetonung und des versrhythmus. Ich citiere, da leider nirgends die verse gezăhlt sind, nach der seitenzahl in Yeowell's ausgabo fur die Aldineedition; die blankverse beginnen daselbst mit s. 112.

\section{Silbenmessung.}

Endungen und ableitungssilben sind zu sondern.

Die flexionsendungen, die -sich, durch consonanz geschütz, erhalten haben, enthalten alle ausser den participien auf -ing ein $e$, also genitivisches und plurales -es, II. sg. -est,

1 Die knittelverse, die 7. b. auch in Shakspere's 'Love's Labour's Lost' und in der 'Comedy of Errors' eine wichtige rolle spielen, und die Delius mit andern 'doggerel rhymes', Abbott 'The comic trimeter' nennt. 
III. sg. -es und -eth, partic. und praet. -ed. Dieses $e$ nun kann je nach bedarf im verse verstummen oder nicht, ganz unabhăngig davon, ob einfache oder doppelte consonanz, oder selbst vocal davor steht. Auszunehmen hiervon ist naturlich -es nach auslautendem zischlaut und -ed nach auslautendem $d$, wenn nicht wie etwa in lend schon dic verschmelzung eingetreten ist. So haben wir:

Spouses ${ }^{126}$, palaces ${ }^{102}$, worldes ${ }^{26}$, times ${ }^{81}$, watches ${ }^{119}$, whalesbone ${ }^{48}$ neben furies ${ }^{28}$, realms auch bereits $\overline{\text { clothes }}{ }^{97}$; so auch ein plur. auf $-n \overline{e y e n}^{4 \cdot 5}$; falleth ${ }^{127}$, cleped ${ }^{129}$, replied ${ }^{154}$, died ${ }^{50}$, closed $^{85}$, rescued ${ }^{120}$, laboured ${ }^{87}$, seeth ${ }^{150}$ u. a. $\bar{m}$. gegenuber flies, fiet $\bar{h}$, discharged ${ }^{43}$, died ${ }^{50}$, absentest, loathest ${ }^{175}$.

Einen unterschied \%wischen schwacher praeteritalform, dem particip in verbindung mit bilfsverben und dem particip in adjectivischem gebrauche, wie dies Schipper (a. a. 0. s. 11) fur Marlowe bemerkt, finde ich bei Surrey nicht.

- Ebenso verhält es sich mit den comparativ-und superlativendungen der adjectiva - obwol rücksichtlich ihres tonwertes das bei der besprechung der wortbetonung gesagte zu vergleichen ist - und mit den starken participien, also: iruest ${ }^{28}$, chiefest ${ }^{32}$, worthiest ${ }^{79}$, faithfullest ${ }^{79}$, gentleest ${ }^{79}$ neben meekest ${ }^{77}$, gentlest ${ }^{77}$, worthiest ${ }^{75}$, fresher ${ }^{37}$ u. a. m. neben nigher ${ }^{37}$, worthier ${ }^{22}$, hidden ${ }^{5}$, frozen ${ }^{13}$, casten ${ }^{37}$, knowen ${ }^{128}$ neben known ${ }^{114}$, befallen ${ }^{26}$, beateñ ${ }^{157}$.

Anders steht es natürlich mit ableitenden -en, -er, Aengl. -nian, -erian, in gather ${ }^{35}$, quicken ${ }^{16}$, fasten ${ }^{18}$, lasten ${ }^{36}$.

Die flexionsendungen, die nicht durch consonanz geschlitzt waren und sich nur hier und $d a$ in einem sogenannten end-e zeigen, verstummten chon im laufe der Mengl. periode, und nur vereinzelt werden sie im 16. jh. noch mitgezăhlt, oft wo sie bistorisch gar keine berechtigung haben. Surrey zeigt nur folgende fălle, die ich durch eine senkung markiere, in den versen:

\section{Lo! what mariner love hath made me \\ 138 Herself in shadow of the close night, \\ 143 The old temple dedicate to Ceres,}

in welchem verse wir wol olde lesen können, wegen des nōtigen stimmabsatzes zwischen $\breve{d}$ und $t$.

113 By the divine science of Minerva.

Letzteren fall möchte ich aus dem grunde so, und nicht etwa 


\section{By the divine science of Minerva}

lesen, weil einerseits Surrey kein beispiel der betonung auf der ableitungssilbe von Romanischen wörtern auf -ence zeigt, und andrerseits Minerva in der betonung Minerve am versschlusse wenige verse weiter erscheint; beide grände sind freilich durchaus nicht zwingend. Es sei dies beispiel darum auch nur als mögliches mitverzeichnet.

Einige andere fălle, die scheinbar hierber gehören, werden bei gelegenheit des feblenden auftactes besprochen werden.

Bei den ableitungssilben haben wir Germanische und Romanische zu unterscheiden.

Die Germanischen sind in den meisten fällen mit der stammsilbe $\mathrm{zu}$ einer silbe verschmolzen, ausgenommen die ableitungen mit -ing, -ness, $-y$ (Ae. -ig), -ly (Ae. -lic), nomina und verba auf -ow (Aengl. - $g$, $-h$ und -gian) und die oben erwähnten verba auf -en, -er. Wo keine verschmelzung eingetreten ist, wird die silbe als senkung mitgezählt, bridle, harvest, finger, winter, maiden, father, lover.

Von Romanischen ableitungssilben sind hinsichtlich der silbenmessung, nur die mit $i(e, u)+$ vocal anhebenden zu erwähnen, -iage, -ian, -iance, -ient, -ier, -ion, -ious, sowie gleichwertige mit $e, u$ statt des $i$, und durch analogie hierhergehörige. Obwol nun Surrey das schleppende, das durch deren beständige vollmessung eingetreten wäre, wol erkannt und daher meist dieselben einsilbig gebraucht hat, wie

Tyrian 153, Lybian 157, patience, conscience ${ }^{69 \cdot 93 \cdot 107}$, patient ${ }^{107}$, ancient ${ }^{160} \cdot 175.127 .132$, soldier ${ }^{132}$, occasion ${ }^{154}$, foundation ${ }^{167}$, motion 159, mansion 175, delicious ${ }^{83}$, righteous ${ }^{96}$, monstruous ${ }^{109}$, plenteous $\overline{96 \cdot 102}$, furious ${ }^{145}$, boisteous ${ }^{165}$, marriage ${ }^{152 \cdot 165}$, assuage 165 u.

so erscheinen dieselben doch am versschlusse in voller messung häufig und da wol an ihrem platze:

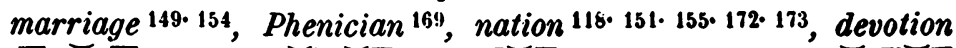
$\overline{129}$, determination ${ }^{174}$, Pygmalion $^{160}$, monstruous ${ }^{162}$, soldier ${ }^{113}$. Und selbst innerhalb des verses finden sich vollmessungen: marriage ${ }^{160.169}$, clergions ${ }^{72}$, guardians ${ }^{144}$, conditions ${ }^{173}$. Am häufigsten erscheint -ion, am wenigsten -ious (-eous, -uous) vollgemessen. 
Abgesehen ron diesen speziellen fallen findet durch $\mathrm{zu}$ sammenziehung und zerdehnung abwechslung in der silbenmessung und dabei oftmals kraftigere ausdrucksweise statt.

Bei ersterer handelt es sich in der regel um die synkope eines wenig betonten $e$ zwischen zwei consonanten, von denen meist einer ein $r$ oder $v$ ist. Die abstammung der wörter ist dabei von keiner bedeutung. Am hăufigsten finden sich die schemen consonant $+e+r+$ vocal, ioraus cons. + $r+$ vocal wird, und vocal $+v+e+$ cons., woraus vocal $+v+$ cons. sich ergibt. Also:

prosperous ${ }^{101}$, boisíerous ${ }^{21 \cdot 116}$, traitrously ${ }^{115}$, moderate ${ }^{96}$, quivering ${ }^{116.119}$, bluslering ${ }^{110}$, liberal, sovereign ${ }^{37}$, uttering ${ }^{24}$, sufferance ${ }^{104 \cdot 108,}$ spirit ${ }^{135 \cdot 93}$ u. ö., und evèn $81 \cdot 83$ u. ö., given ${ }^{98}$, heavens ${ }^{61.63 .108}$, ever ${ }^{111}$, every ${ }^{9}$, savoury ${ }^{90}$, marvellous ${ }^{111}$.

Daran schliessen sich wörter mit auslautendem $r$ Germanischer und Romanischer abstammung in gleicher weise: fire ${ }^{144}$ und fire ${ }^{141}$, sour ${ }^{45}$, our ${ }^{89 \cdot 109}$ und our $^{6}$ u. o., tower ${ }^{114}$, power ${ }^{118 \cdot 119 \cdot 33}$ u. o., devour ${ }^{31}$.

Neben den erwăhnten, am häufigsten vorkommenden făllen, findet sich dies naturlich auch bei andern consonanten, wie venemous ${ }^{131}$. Das gegenteil von der zusammenziehung ist die zerdehnung, die, wo der vers dessen bedarf, ein $e$ zwischen zwei consonanten einschiebt. Die hier vorliegenden fälle lassen sich gewissermassen als vollmessungen auffassen, die in der schrift nicht ersichtlich sind. Sie sind in den versen:

22 In ship, freight with remembrance
149 Also the Sirtes unfriendly harbrough
57 Ne by coward dread in shunning storms dark.

$\mathrm{Zu}$ erwähnen ist noch synhaerese oder synaloephe zweier wörter, deren erstes vocalisch auslautet und deren zweites vocalisch anlautet, sn:

Th'entry ${ }^{122}$, to annoy ${ }^{114}$, manya ${ }^{21}$, beauty of ${ }^{13}$.

Zusammenziehung taber das wort hinaus:

render unto ${ }^{70}$, father Anchises ${ }^{161}$.

Uebrigens scheint es viel wahrscheinlicher, dass dergleichen falle nicht als contractionen, sondern jé zwei silben im zeitmasse einer zu lesen seien. Man vergleiche damit die uberzahligen silben im versrhythmus. 
2. Wortbetonung.

In der behandlung des worttons liegt zum grösten teile Surrey's bedeutung für die geschichte der Englischen metrik, indem bei ihm die hebungen des versrhythmus bereits mit dem Nengl. hauptton der wörter im wesentlichen, bis auf verhăltnismässig wenige uberreste aus Mengl. zeit, in einklang stehen.

Freilich haben wir ausser den reimsilben kein anderes kriterium des tonwertes einer silbe, als die fähigkeit hebung oder senkung zu tragen, und es ergibt sich nur die regel, dass jede betonte silbe, die durch eine senkung von der in jedem falle gehobenen stamnsilbe getrennt ist, die hebung tragen kann. Wir erbalten deshalb ableitungs- und endungssilben in der hebung, und naturlich umgekehrt $z$. b. einsilbige worte auch in der senkung, trotz ilures haupttons fur sich. Im reime aber erscheinen nur folgeude ableitungs- und endungssilben, die uns doch ein wenig uber die tonwerte belehren: -ly : -ty : -y : high : cry : be : me, -ness, -ous, Romanisches -er (counsellor : conforter ${ }^{77}$ ), -ment, sowie die superlativendnng -est (roorthiest: faithfullest ${ }^{77}$, worthiest : gentleest ${ }^{79}$ ).

Die Germanischen wörter bieten somit wenig bemerkenswertes. Als rest Mengl. freiheit, als letzten fuss ein paroxytonisches wort zu gebrauchen, finden sich nur folgende zwei verse:

136 Home to her spause, her parents and children und

175 With wailing great and women's shrill yelling.

Nicht ausser acht zu lassen ist, dass die betreffenden endsilben einen starken nebenton besassen. Analogen fallen im versinnern werden wir noch begegnen. Von schwankenden betonungen zusammengesetzter wörter Germanischen ursprungs wird ausfuhrlich bei gelegenheit der in den versrhythmus eingemischten trochaeen die rede sein. Sicher sind nur folgende, durch den versschluss verburgte fălle:

\footnotetext{
15 Heaven and earth disturbed in nothing : bring

156 Thal now in larthage loitereth, rechless

114 And but for fates, and for our blind forecast

126 And Rypheus that met us by moonlight

141 Which with much light gliding on the house top

142 That come but late from slanghter and bloodshed.
}

Die betonung der wörter Romanischer abstammung wurde nach Germanischen prinzipien in angriff genom- 
men, und wir finden bei Surrey im ganzen schon den standpunkt unseres heutigen Englisch. Die abweichungen erscheinen in der regel als gelegentliche uberbleibsel, gegentiber den uberwiegend zahlreicheren fällen derselben art mit moderner betonung.

Es ist diesbezliglich von interesse, dass Gascoigne in seinen 'Notes of Instruction' s. 33 mit aller entschiedenheit auf dio richtige betonung im verse dringt: 'And in your verses remembre to place every worde in his natural Emphasis or sound, that is to say in such wise, and with such length or shortnesse, elevation or depression of sillables, as it is commonly pronounced or used' - tréasure und nicht treasire.

Die häufig willkurliche tongebung besonders bei jenen nominibus und verbis, die mit praepositionen zusammengesetzt sind, gestattet uns fur beute keine feste regel aufzustellen, geschweige denn fur die fruhere zeit. Es genligt zu bemerken, dass die betonung uberall die heutige ist, wo das gegenteil nicht besonders hervorgehoben wird.

Die regel, dass bei gleichlautenden nominibus und verbis, erstere die praeposition, letztere die stammsilbe mit vorliebe betonen, findet sich auch bei Surrey, als die naturliche folge der ableitung der verba von der 1. pers. sg. praes. im Afrz. Diese differenzierung erscheint aber doch noch nicht so weit durchgeführt.

Wir finden die substantiva torment ${ }^{2 \cdot 34}$, record ${ }^{27}$ gegenuber den verbis torment 25.30 .34 , record $\overline{{ }^{20}}$, doch noch discord ${ }^{6.87}$, compact ${ }^{107}$, compass $\overline{5}{ }^{5 \cdot}{ }^{108}$, conflict $\overline{85}$ als substantiva.

Andrerseits ist die erscheinung der nach heutigem sprachgebrauch zu weit gegangenen zurtuckziehung des tones zu constatieren, in mebreren fallen, wobei ich jedesmal den ganzen vers mitteile:

68 For to break for did convert so, daneben to convert ${ }^{13.61}$.

134 Which repuls'd from the brass where it gave dint neben dem substantivum repulse ${ }^{38}$.

114 The suspect present of the Greek's deceit,

148 Of Afric breeds, in honours triumphant,

138 And Jupiter my father distributes,

94 Than their importune suits, which dream that words God's wrath appease (auch heute neben importrine). 
Um die reste Romanischer betonung in Romanischen worten vorzufuhren, düfte es zweckdienlich sein, dieselben nach ibren ableitungsilben, wie diese im Englischen erscheinen, zu ordnen. . Sicher sind nur die fälle am versschlusse, nicht so die im innern des verses. ${ }^{1}$ Es wird daher auch da nōtig sein, die betreffenden verse ganz herzusetzen. Naturlich ist es höchst wahrscheinlich, dass in der gewöhnlichen rede, die betonungen weniger schwankungen unterlagen; im vers aber bediente man sich dieser freileiten, die damals eben nicht so sebr als verstōsse gefuhlt wurden, wie heute: Diese mangelnde scheu vor unenglischen betonungen, und deren umfang allein ist es, was sich aus den gesammelten beispielen beweisen låsst.

-ace bietet in den versen

174 Into the inward wards of her palace und

132 But the palace within counfounded was

Romanische betonung gegenüber den überwiegend zahlreicheren fällen von palace 127 . 133. 135 . 150.175.

-age durchans image ${ }^{135}$, bondage ${ }^{20}$, vantage ${ }^{34}$, visage ${ }^{60}$, courage ${ }^{114} \cdot 138$ u. a. m., und im verse Thrice did my hands vain hold $\bar{t}$ 'image escape $^{\text {its }}$ ist wol nach einer logischen pause ein trochaeus wirkungsvoll.

-ail, - el Afr. aille, eille, elle, el in den zwei versen

82 The end of each travail forthrith I sought to know und

106 Care pierceth my entrails, and travaileth my spirit

Romanisch betont, gegenüber travail 2. 36. 60 , auch to travail 106 , entrails ${ }^{150}$, marvel, parcel ${ }^{3}$, vessel ${ }^{144}$, sequel ${ }^{61}$, mantle ${ }^{122}$, castle $^{71}$ bätle $\overline{\text { T.zo }}$ u. dgI. m.

$-a$ in in

57 Lightnings assault the high mountains and clives

112 The Greek chieftains all irked with the war

122 The great captains, Sthenel and Thessander

gegenüber mountain ${ }^{71}{ }^{138}$, foreign ${ }^{10}$, Britain ${ }^{13.68}{ }^{68}$, sover eign ${ }^{37}$, certain ${ }^{70}$; etymōogisch bierhergehörig und dorzeitig anch häufig noch so geschrjeben

107 With such sudden surprise, quick may him hell devour gegenuiber zahllosen fällen heutiger betonung sudden 8. 55.69.85. 120 u. 6.

-al, -el in By our spousals and marriage begun ${ }^{160}$ gegentiber mar-

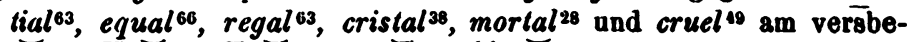
ginne sicher wie in allen andern fällen cruel zu lesen.

1 Abbott (Shakesp. Gr.) nimmt keinen anstand, jedes wort zu betonen, wie es der rhythmus verlangt. 
-ance, -ence durchgängig Englisch betont: silence ${ }^{11 .} 100$ u. 8 ., conscience $^{60.03}$, presence ${ }^{80.149}$, countenance ${ }^{73 .}{ }^{77}$, constance ${ }^{41} \mathrm{u} . \mathrm{dgl} . \overline{\mathrm{m}}$. also wol auch science ${ }^{113}$.

-ant, -ent im verse Of his parints before their face fell down 18 neben parents ${ }^{136 .}{ }^{140}$, ancient ${ }^{160 .}{ }^{175}$ n. $2 . \mathrm{m}$.

-er sowol Lat. arius als auch Lat. arium, erium entsprechend:

75 And by thy looks and thy manere:

reimend mit chere,

57 Void of dangers advisedly hath his home

162 From death's danger his fellows eke defend

141 If by prayer, almighty Jupiter.

gegenliber danger 102. 143. 170, banner ${ }^{12}$, prayér ${ }^{125.160}$, pillar ${ }^{133}$, river ${ }^{71}$. In dem verse Shall 1 wait? or board them with my power ${ }^{170} \mathrm{zu}$ lesen power wäre doch suffallend, zumal da das wort so häufig einsilbig uñ im reim mit devour $\mathfrak{u}$. dgl. vorkommt; wir erwarten die erste bebung auf Shall, was durch annabme eines fehlenden anftakts möglich ist. Etymologisch gehört hierher auch laurel, Afrz. laurier,

133 An old laurel tree, bowing thereunto.

-esse durch den schluss verbtirgt: Worship was done to Ceres the Goddess ${ }^{112}$ and ebenso Unto the son of Venus, the Goddes $s^{145}$ gegenuber sonstigem godess ${ }^{119 .}$ 124. 137. 155 , fortress ${ }^{125}$.

- et in diminutivableitungen, participialendungen $\mathrm{u}$. dgl.:

117 Salt corn, fillets, my temples for to bind

130 A postern with a blind wicked there was

69 In most quiet, are next ill rest

gegenulber fillet ${ }^{121 \cdot}{ }^{124}$, billet ${ }^{168}$, turret ${ }^{57}$, planet ${ }^{79}$, target $^{121}{ }^{\text {, quiet }}{ }^{\text {(4) }}$ u. ö., secret $\overline{00} \mathbf{u} . \ddot{8}$.

-est The wild forest, the clothed holts with green 20 , gegenuber honest.

-i Lat. -icus, Encmie 70 nicht sicher da am versanfunge, gegenúber sonstigem eñemie ${ }^{67 .} 141$ u. 8.

$-i l e,-i l$

28 Good ladies! ye that have your pleasure in exile

139 Or bide exile, after the fall of Troy,

145 A long exile, thou art assigned to bear,

84 What raging pleasures past, peril and hard escape

letzterer fall unwahrscheinlich, da nach der pause; daneben peril 57. 142. 144.

-in 129 Of the Virgin from them so rescued,

130 And coverd with engines the gate beset, gegenüber virgin ${ }^{119}$, engine ${ }^{118.110 .}{ }^{123}$, cousin ${ }^{62}$. $-i v e,-i f$

143 From me catif, alas! bereaved was

160 Hiarbas, yet captive lead me arvay

115 May me receive? Catiff what rests me now daneben caitif ${ }^{120.121}$, native ${ }^{122 .}{ }^{123}$. 
-ie, $y$; Lat. ia; Frz. ie

137 Sou! what fury had thus provoked thee

59 Lurked, whose breasts envy with hate had swoln,

hier ist auch ein trochaeus möglich; desgl. 8. 45.

172 What said I? but where am I? what phrensy, gegenuiber fury ${ }^{28.166}$, envy ${ }^{61.09}$, phrenzy ${ }^{114}$, navy ${ }^{131}$, fancy ${ }^{17 .}{ }^{73 .}$ is 11. a. $\mathbf{m}$.

$-i e, y$; Frz. é, it

i32 As in th' entry of slaughter furious,

desgleichen pity ${ }^{75 .}{ }^{118}$, doch am versanfange; sonst entry ${ }^{132 .}{ }^{116}$, pity ${ }^{27.75}$, mercy ${ }^{11 \cdot}{ }^{18}$, valley 1 , beauty ${ }^{61}$.

-ish 63 Did yield, vanquisht for want of martial art,

nach einer logischen pause leicht trochaeisch zu lesen, bei sonstigem vanquish ${ }^{226 .}$ 127. 130. 140. 149, languish ${ }^{7}$ anguish ${ }^{30}$, flourish ${ }^{115}$.

-on, $-i o n$

13 Whose moist poison dissolved hath my hate,

149 The ships shaken, unfriendly the season,

3 The soote season, that bud and bloom forth brings,

97 The bitter gall, season'd with sweel, suck wisdom may digest,

letzterer fall nach der pause leicht trochaeisch zu lesen, wie sonstiges season, pardon ${ }^{98}$, guerdon ${ }^{163}$, treason ${ }^{122}$, prison ${ }^{19.20} \mathrm{u} . \ddot{0}$.,

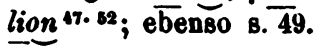

$-o r,-o u r$

166 In great honour and worship, which she held,

143 With that bright shields and shene armours I saw,

128 Our first labour, thus lucked well with us,

daneben honour ${ }^{18 \cdot}{ }^{147}$, armour ${ }^{128 .}{ }^{133}$, dolour ${ }^{27}$, favour ${ }^{18}$, vapour ${ }^{16}$, labour ${ }^{38 .}$

-ure; Frz. - ure und -ir

132 Whom the closures ne keepers might hold out,

(wie hente:

156 To whom we gave the strand for to manure,

137 And plenty of grisly pictures of death

gegenuber closure ${ }^{69}$, measure ${ }^{2}$, pleasure ${ }^{71}$ u. ö., picture ${ }^{147 .}{ }^{168}$ u. dgl. $\mathbf{m}$.

$-u n e$

115 A Grecian born, for though fortune hath made,

174 I lived and ran the course, fortune did grant,

letzterer fall wieder nicht nütig, da nach einer pause; auch sonst fortune ${ }^{45}$.

Ausser diesen fällen möglicher Romanischer betonung, die durch die uberwiegenden falle Englischer betonung derselben wortarten als vereinzelte uberbleibsel $\mathrm{zu}$ bezeichnen sind, sind noch einige wörter zu erwähnen, die nicht unter obige gruppen 
zu bringen sind, oder bei denen die ableitungssilbe als solche nicht mehr im sprachbewustsein gefülilt werden konnte:

58 To Wyatt's Psalms should (hristians then purchase (:grace)

32 Of Venus' face, triumph'd in painters art,

hier wieder nach der pause, wobei das schon erwähnte triumphant ${ }^{148} \mathrm{zu}$ vergleichen ist.

107 It was the Lord that brake the bloody compacts of those

57 Of thy life, Thomas, this compass well mark,

85 The wailful wrongs und hard conflicts that folly doth endure

ferner wie schon erwähnt, zweimal discord im reime auf accord ${ }^{6}$ : Lord ${ }^{87}$.

56 The mean diet, no delicale fare.

$\mathrm{Zu}$ erwähnen wăre etwa noch die behandlung der silben -le und -re; erstere in der regel auf Frz. -elle, -el, -ile zurlickgehend, letztere z. b. in verben wie Afrz. sufrir, nur durch das stummwerden der infinitivendung einen ton erhaltend. Beide silben finden sich, wie zu erwarten, nur in der senkung, wenn nicht vor folgendem vocal stumm; z. b. subtly ${ }^{145}$, gentlest ${ }^{77}$ und gentleest ${ }^{79}$ (andere beispiele bei der ableitungssilbe -aille), offer ${ }^{11}$, suffereth 118 u. a. m.

Besonderer besprechung bedurfen die eigennamen. In deren silbenmessung und wortbetonung herscht die grösste regellosigkeit.

Beztglich der silbenmessung finden die freibeiten der zusammenziehung und zerdehnung in ausgedehntem masse statt, 2. b. Zephyrus ${ }^{81}$, Lacon ${ }^{120 .} 121$ und Laocoon ${ }^{114}$, wie Laocoon ${ }^{120}$ u. a. m. Vollmessungen sind häufiger als bei anderen wōrtern innerlalb des verses: Ascanius 140. 172 neben Ascanius 143. An den beispielen ersehen wir zugleich die betonung, die wol durch das Latein, das im Virgil vorlag, beeinflusst worden sein mag. Atride 116, Atrides 129, Neptune s5, Neptunus 120. 137, Carthages ${ }^{140} .{ }^{100}$, Carthage ${ }^{138 .}{ }^{175}$, Panthus ${ }^{125 \cdot}{ }^{129}$, Panthus ${ }^{126}$, Hector $^{128}$ und Hector ${ }^{133}$ u. dgl. $\mathrm{m}$.

Die betonung des namens Chaucer, gegen die sich nicht einmal Occleve versundigt, findet sich im verse

That reft Chaucer the glory of his wit

nach Romanischer art; ob man eine härte im rhythmus annehmen sall, ist wol nicht zu ontscheiden. 
Der name Wyatt ist s. 67 einsilbig gemessen, eher werden wir wol zweisilbige senkung annehmen: But Wyatt said true; The scar doth age endure, sonst findet er sich zweisilbig.

\section{Versihythmus.}

Was den versrhythmus anbelangt, ist es nicht leicht, ein entscheidendes urteil $\mathrm{zu}$ fällen. Streiten doch eben jetzt die Englïnder selbst uber den rhythmischen gang der verse Shakspere's, Milton's, 'Tennyson's (s. Transactions of the Philological Society $1874 / 5-1875 / 6)$. Wie soll man dann über verse aus der ersten hälfte des 16 . jh. sich entscheiden?!

Interessant ist in der hinsicht die diesbeztugliche stelle in Gascoigne's Notes 8. 33 ff., die, wie es scheint, nicht so beachtet ist, wie sie es verdiente. Ich will das wichtigste hier einrticken:

'For furder explanation hereof, note you that commonly now a dayes in english rimes (for 1 dare not cal them English verses) we use none other order but a foote of two sillables, wherof the first is depressed or made short, and the second is elenate or made long: and that sound or scanning continueth throughout the verse.' - - - 'We have used in times past other kindes of Meeters: as for example this following:

No wight in this world, that wealth can attayne, Uñlesse hì bileiue, thàt all is bùt váyne.

Also our father Chaucer hath used the same libertie in feete and measures that the Latinists do use: and whosoener do peruse and well consider his workes, he shall finde that although his lines are not alwayes of one selfe same number of Syllables, yet beyng redde by one that hath understanding, the longest verse and that which hath most Syllables in it, with fall (to the eare) correspondent unto that whiche hath fewest syllables in it: and like wise that whiche hath in it fewest syllables, shalbe founde yet to consist of woordes that haue suche naturall sounde, as may seeme equall in length to a verse which hath many moe sillables of lighter accentes. And surely I can lament that wee are fallen into suche a playne and simple manner of wryting, that there is none other foote used but one: wherby our Poemes may justly be called Rithmes, and cannot by any right challenge the name of a verse'.

Die zeit der abfassung dieser schrift wird zwischen $1572--1575$ gesetzt. In seiner 1566 erschienenen 'Jocasta' hat Gascoigne seine regeln noch nicht so streng beobachtet wie in seinem 1576 erschienenen 'Steele Glas'. Dies ist in 
metrischer hinsicht wol eine musterdichtung zu nennen. Jedenfalls beweisen Gascoigue's sätze auf das entschiedenste, dass far soine zeit der jambische rhythmus nicht in frage gestellt werden kann. Und dass Gascoigne ein glied in der kette ist, die von Surrey zu Shakspere fuhrt, ist wol nicht zu leugnen.

Was dachte sich aber Gascoigne unter den 'feete and measures that the Latinists do use'?

Vermutlich einerseits die scheinbare einmiscliung von dactylen, anapaesten u. dgl., welcher schein durch die nötigen verschleifungen und die zweisibigen senkungen entstand, andererseits die gelegentlichen Romanischen betouungen Romanischer wörter und die schwankenden in den Germanischen. Woher der citierte vers, der alliteration zeigt, ist, kann ich nicht finden; er Lat die in der einleitung erwähnte form, die sich in den dramen der zeit - für Gascoigne jedenfalls nicht in 'times past' nur - sehr hăufig findet.

Das 'Steele Glas' enthält strengste beobacbtung des jambischen rhythmus, bis auf ganz wenige trochaeen im versanfange, strengste beobachtung des Englischen worttons. Hs ist nicht von dem dichter, der im sturme cles lebens steht, es ist von dem bejahrteren, theoretisierenden manne, im vorletzten jabre seines lebens. Seine loblichen prinzipien der metrischen reinigung der poesie, sind daher nicht in aller strenge den dichtungen der zeit anzupassen, und sind glucklicherweise auch nicht so befolgt worden.

Nichtsdestoweniger ist aus Gascoigne's prinzipien viel nutzen fur die erklärung der metrik des 16. jh. zu ziehen, denn sie zeigen sich bei Surrey; Grimoald, Spenser u. a. wol bewährt, wenn auch freilich mit diesen und jenen freiheiten. Durch Gascoigne's schrift haben wir einen sichern ausgangspunkt gewonnen; er bezeichnet, wie wir es heute tun, die betreffenden dichtungen als jambische, wenn er sich auch ziemlich unklar uber die accente ausdruckt, die or in gravis, lenis und circumflex einteilt und folgendermassen characterisiert:

'the grave accent (') is drawen out or eleuate and maketh that sillable long, whereupon it is placed: the light (') accent is depressed or snatched up, and maketh that sillable short upon the which it lighteth: 
the circumflexe accent $(\mathcal{)})$ is indifferent, sometimes short, sometimes long, sometimes depressed and sometimes eleuate'.

Die begriffe der länge und kurze, arsis und thesis, gehen durcheinander, wie etwa hundert jahre später bei den Deutschen metrikern, obne dass aber Gascoigne uns mitteilt, welche silben er lang, kurz oder mittelzeitig misst.

Um zu Surrey zurickzukehren, ist zu bemerken, dass seine sämtlichen dichtungen, ganz abgesehen von ihrer einteilung nach reimfiguren, sich als jambische ergeben. Neben zwei 3 ftissigen, zehn 4 füssigen, einem nicht glucklichen versuch in reimlosen alexandrinern, finden sich neunzehn dichtungen in der, vermutlich von Surrey eingefubrten, im 16. jh. 80 beliebten verbindung von alexandriner und 7 fussigem jambus, abgefasst. Weitaus die gröste zahl aller gedichte aber ist in 5 fussigeu jamben geschrieben, vierundzwanzig in gereimten und die ubersetzung des zweiten und vierten buchs der Aeneide in blankversen.

Ich legre also für meine untersuchung samtlichen gedichten Surrey's streng jambischon rhythmus schematisch $z u$ grunde, und beurteile von dem standpunkte aus die einzelnen widersptuche, obwol, wio in der einleitung gesagt wurde, mit denselben nicht so streng in's gericht gegangen werden darf, da durch den einfluss des silbenzăblenden prinzips der Romanischen poesie das gefuhl für den rhythmus etwas abgeschwächt war.

Ueber alle seiner zeit gebräuchlichen versarten - freilich nur uber die, welche er fulr kunstmăssig hielt - gibt Gascoigne uns aufschluss; dass er den blankvers nicht ausdrücklich erwăhnt, ist wol auffallend. Dennoch ist eine stelle von wichtigkeit, a. a. o. s. 3j:

'I would exhorte you also to beware of rime without resson: my meaning is hereby that your rime leade you not from your firste Invention ... But do you alwayes bold your first determined Invention, and do rather searche the bottome of your braynes for apte words, than chaunge good reason for rumbling rime'.

Interessant ist, was Gascoigne uber einen sehr wichtigen factor in verse sagt, uber die pausen. Die auffassung derselben ist so wichtig, dass ich wieder Gascoigne selbst sprechen lassen muss, a. a. 0. s. 37 f.:

'There are also certayne panses or restes in a verse, whiche may be called ceasures, whereuf I woulde be lothe to stande long, since 
it is at discretion of the wryter, and they have bene first devised (as should seeme) hy the Musicians: but yot thus much I will adronture to wryte, that in mine opinion in a verse of eight sillables, the panse will stand best in the middest, in a verse of tonne it will best be placed at the ende of the first foure sillables, in a verse of twelve in the midst, in verses of twelve in the firste and fouretene in the second, wee place the pause commonly in the midst of the first, and at the ende of the first eight sillables in the second. In Rithme royall, it is at the wryters discretion, and forceth not where the panse be untill the ende of the line'.

Die ersten zeilen bezeugen uns die anschaung damaliger zeit uber die pausen im Englischen verse, so wie wir sie heute uns aus den verschiedenen perioden entwickeln. Im Englischen verse ist die-pause in erster linie ein logischer rubepunkt. Dem entsprechend wechselt dio pause mit ihren stellen von Chaucer bis auf unsere zeit, ja sie fehlt in manchen versen im innern ganz, steht also erst am versschlusse. Bei Surrey nun findet sich im 8- und 12 silbler die pause in der mitte und der 14 silbler lăsst, wie Gascoigne angibt, eine pause nach der 8. silbe eintreten; ich setze noch eins zweite nach der 4. silbo an. Diese rhythmen zerfallen durch ihren bau vaturgemäss in solche teile, daneben finden sich logische pausen, unabhăngig von diesen gesetżen. Far den 10 silbler kommt es sun auf 'the wryters discretion' an, sich sclaviseh an das schema der pause nach der vierten silbe, wo sie naturlich am besten passt, zu binden, oder die freiheit, die in dom verse wie in keinem andern liegt, zu gebrauchen; sagt doch Gascoigne auch vom rhythm royal 'it forceth not where the pause be untill the ende of the line'. Dio freiheit bezluglich der pause ist es wol, die den 10 silbler einerseits, und ein weiterer bofreiender schritt, das aufgeben des reimes andrerseits, der den blankvers so beliebt gemacht hat. Auf die notwendigkeit der ruhepunkte im verse ist nun die wicttigste unregelmåssigkeit des jambischen verses gestutzt, das eintreten von trochaeen an die stelle von jamben.

In einem verse von jambisobem rhythmus muss ein wort, das sich demselben nicht leicht fugt, naturgemăss denselben auflualten. Am anfange des verses, im eraten fusse ist der dichter noch nicht in den rhytbmus gekommen; dureh einen troobaious an dieser stello ontoteht also keine pause wie im imern des "verses; "ist nur ein dusdruckliction hervorheben 
des nun folgenden verses im verhältnis zu den ihn umgebenden verszeilen zu erkennen. Im innern des verses aber ist der rhythmus durch einen trochaeus unterbrochen, und es ist dabei nun zu unterscheiden, ob eine so entstandene pause der logischen verwendung des betreffenden wortes entspricht, oder nicht. Ist ersteres der fall, so haben wir es mit der von Mommsen und Schipper besprochenen belebung des verses zu tun; im andern falle, wie immer derselbe auch zu erklären ist, empfinden wir härten im versrhythmus.

Ich beginne die besprechung der den versrhythmus belebenden trochaeen, da beim 6 silbler sich keine finden, mit dem 8silbler. Natürlich finden sie sich am häufigsten an erster stelle, so:

12 Furthering his hope, that is his sail u. a.m.

Dazu ein beispiel eines blos durch die satzbetonung veranlassten trochaeus, was Mommsen einen rhetorischen trochaeus nennt:

23 Thus is my wealth mingled with woe,

worin zugleich ein beispiel fur den trochaeus an dritter stelle nach der pause gegeben ist, ebenso:

45 Since fortune's wrath envieth my wealth und

46 The frozen thoughts graven by love,

desgleichen rhetorisch:

69 Thy windows had done me no spight.

Da der 10 silbler eingehendere besprechung erheischt, gehe ich vorher an den 12 - und 14 silbler.

Im 12silbler findet sich der trochaeus sehr băufig an erster stelle, z. b.:

45 Under a mulberry tree it was; first said the one andere beispiele auf s. 49, 50, 84, 87, 97, 108, 111.

Sonst findet er sich noch an vierter stelle nach der pause:

100) Within this careful mind burden'd with care and grief, ebenso s. 91, 107.

Sonstige trochaeen sind als härten zu bezeichnen, doch einer nicht; im verse: Behold! hearken in grief, lamenting how I pray ${ }^{106}$ lehrt uns der trochaeus im zweiten fusse nach einer grössern logischen pause so recht, wie wir tuberhaupt die trochaeen aufzufassen haben. 
Im 14 silbler finden wir die trochaeen an erster stelle und an der dritten und funften stelle nach der ersten und zweiten pause:

90 Gather may he that savoury fruit, that springeth of his pain,

ebenso s. 24, 80, 84, 87, 90, 95, 102, 103, 104, 109.

81 What new device | grounded so sure | that dreadeth not to fall, ebenso s. $82,93,95,103$.

95 Whereto thy heart | to bind thy will | freely doth not accord.

Der 10 silbler, der bei weitem die meisten verse Surrey's beherscht, bietet hinsichtlich der trochaeen die reichste ausbeute, und zwar der gereimte, wie der blankvers; letzterer freilich zeigt noch grōssere mannigfaltigkeit.

An erster stelle finclen sich die meisten beispiele, unter denen ich nur wenige hervorhebe. So s. 145 sebr wirkungsvoll:

Where Lidian Tiber with his gentle stream Mildly doth flow along the fruitful fields.

und ebenso syntaktisch s. 17, rum schlusse des sonetts 'A vow to love faitlifully, howsoever he be rewarded', nach aufzăblung der verschiedensten hindernise:

Hers will $I$ be, and only with this thought

Content myself, although my chance be nought.

An erster stelle sind die fälle so hăufig, dass eine aufzăhlung derselben unnatz wäre; zwischen gereimtem 10silbler und blankvers besteht darin kein unterschied.

Die pause kann im 10 silbler nun nach der vierten, funften oder sechsten silbe eintreten, doch binsichtlich eines nachfolgenden trochaeus kann nur die nach der vierten oder sechsten silbe in betracht kommen.

An dritter stelle nach der pause finden wir den trochaeus zweimal im gereimten 10 silbler:

19 Where we did strain | trained with swarms of youth

98 After long war I patience had oppress'd,

doch ungleich hăufiger im blankvers:

120 With glowing eyen | tainted with blood and fire, ebenso s. 113,127, 128, 129, 130, 132, 133, 135, 138, 139, 140, 141, 142, 144 u. ö.

Hat in dieser lebendigkeit der blankvers schon etwas vor dem gereimten 10 silbler voraus, 80 ist dies noch mohr der fall bei den trochaeen an vierter stelle nach einer pause, 
dic sich in den gereimten 10 silblern gar nicht finden, wol aber häufig im blankvers:

133 And ran amid his foes | ready to die,

165 So hard to overtreat? | whither whirls he?

und ebenso auf s.113, 145, 149, 154, 155, 157, 171, 174.

Auch im blankvers findet sich ein trochaeus an zwciter stelle nach einer logischen pause, freilich selten wie eine solche pause:

118 The Greeks; lawful to hate their nation.

169 Were sought, after the right course of the moon

In gegensatze zu diesen trochaeen, deren anwendung unser ohr heute noch erfreut, sind solche $z u$ verzeichnen, die ich unter dem gemeinsamen namen von härten begreife: trochaeen, die den fluss des verses unterbrechen, ohne syntactische motivierung. Dass dieselben vermutlich unter dem einflusse Romanischer poesie vom dichter selbst nicht so hart empfunden wurden, ward schon bemerkt. Auch wird die weiterentwicklung zeigen, wie sie allnählich in der Englischen metrik mehr und mehr verschwanden.

Unter den bărten sind aber abstufungen nach dem grade der härte deutlich zu erkennen. Es wird sich dadurch manches zu gunsten des dichters gestalten.

1. Bei der wortbetonung wurden die schwankenden betonungen Germanischer composita, die durch den versschluss verbügt waren, anfgezählt. Im versinnern finden sich noch mehrere falle, die einzeln vorgefuhrt werden müssen:

176 Herself upward; and thrice she overthrew

144 Holding backward the steps where we had come (ebenso:

106. Give ear to my suit Lord! from ward hide not thy face und

122 from Tenedon towards' the coasts well known,

doch ist hier ein trochaeus nicht auffällig).

128 Ay me! bootless it is for any wight,

auch hier ist ein trochaeus nicht unmöglich.

11i With blood likenise, ye must scek your return

154 Speedy of foot, of wing likewise as swift

2 And brought the day, it doth nothing abale

125 His next neighbour Ucalegon afire

- Was Abbott veranlasst, einige fälle von toward bei Shakspere anzumerken, verstehe ich nicht, da nach Webster (Synopsis of words differently prononnced by different orthoepists, in 8. Dictionary) die heutige ausoprache auch townard ist. 
155 Aeneas one outsprung of Troyan blood

156 Ne his off spring in Italy regards

131 With young Astyanax his grandsire to see

157 From his grandfather by the mothers side

19 As proud Windsor? where 1 , in lust and joy.

Koch Gr. I 153 bespricht diese erscheinung nur kurz. Abbott in seiner Shakesp.-gr. fuhrt mehrfache belege für versetzte betonung an, ohne gerade composita von andern wörtern za scheiden. Ich glaube aber entschieden, dass composita besonders zu betrachten sind und die betonung derselben der willkür am meisten ausgesetzt war, ebenso wie im Deutschen verse im 16., 17. und 18. jh. und vereinzelt noch heutzatage zweiteilige worter gelegentlich im tone wechseln kønnen.

Die versetzten betonungen am versschlusse berechtigen uns zum mindesten, die moglichkeit schwebender betonung und daher das fallen der hebung auf den zweiten bestandteil, im versinnerń, anzunehmon. Zudem finden wir besonders wörter wie likewise, nothing damals noch häufig getrennt geschrieben.

Besonderer erwähnung bedarf das wörtchen unto, sowie das etwas seltner vorkommende into. Koch Gr. I 168 berührt die frage nur kurz. Er citiert eine stelle aus Robert Herrick's (1591-1674) 'Night Piece to Julis', die uns für beide worte im reim die versetzte betonung bietet. Sie lautet:

Then Julia, let me woo the e

Thus, thus to come unto me;

And when I shall meet

Thy silvery feet,

My soul l'll pour into the e.

Bei Surrey stebt die sache folgendermassen: unto steht etwa neun mal, into etwa fünf mal, doch nach einer pause, so dass durch einsetzung eines trochaeus die regelrechte betonung ungestort bleibt, z. b.:

117 Returned all unto my wretched death oder

19 With cyes cast up into the maiden's tower.

Daneben zähle ich etwa acht fälle, wo die regelmässige betonung unto durch den rhythmus gewahrt ist, z. b.:

125 Whath prick'd us forth; and unto us it seemed.

Hingegen aber finden wir in den versen:

30 And then unto myself 1 say; when we shall meet

61 To swell in wealth, or yield unto mischance

65 That opes and shuts as I do speak, do thus unto me say

109 (Thou) hast put int to such infants' mouths for to confound their pride

die versetzte betonung wahrscheinlicher. Freilich konnten wir uns ja ganz leicht helfen, indem wir Surrey härten zuschreiben, deren or $j a$ mehrere anfunweisen hat. Doch warum? Bcheint es nicht vielmohe 
wahrscheinlich, dass das Englisch des 16. jh. noch nicht so erstarrt war, wio das heutige, so dass dergleichen zweiteilige worte noch als solche gefiihlt und gebraucht wurden, wie etwa gelegentlich unser Nhd. dazu? Bei gelegenheit der besprechung von Gascoigne's 'Steele Glas' müssen wir darauf noch zuruickkommen. Die erklärung dieser erscheinung bei Abbott (der aber wol nicht die absicht hatte, alle fälle zu verzeichnen), Shakesp.-gr. 337, erscheint beachtenswert, wenn man die auseinandersetzung über das verhältnis von to zu unto bei Mätzner, Gr. II 326, heranzieht.

Bieten nun diese möglichen fälle schwankender betonung eigentlich nichts characteristisches für Surrey, so finden sich bei ihm doch noch andere härten, die seine vorgänger wol in weit höherem masse aufweisen, indem sie die betreffenden wortgattungen sogar im letzten fusse und im reime verwenden, die aber in den weiteren blankversdichtangen möglichst gemieden werden.

2. Gewisse wortgattungen scheinen durch ihren starken nebenaccent - natürlich handelt es sich da nur um zweisilbige worter dazu verleitet zu haben, die stammsilbe in die senkung zu setzen. Graphisch wäre so ein fall etwa durch einen spondeus darzustellen. Adverbia und adjectiva auf -ly, participia auf -ing, superlative auf -est a. dgl. m. sind die gewöhnlichsten fälle.

Die verse müssen einzeln zur veranschaulichung vorgeführt werden:
57 Whoso gladly halseth the golden mean
58 And so wisely when lucky gale of wind
67 For such calling when it works none amends
132 Not so fiercely doth overflow the fields
143 She was only away, deceiving us
127 And plenty of grisly pictures of death
175 And her dying she clepes thus by her name
145 And there wondring I find together swarm'd
124 The dim resounded, with ratiling of arms
126 The cry greatest that made the air resound
116 Yea and either Atride would bye it dear'
176 For that neither by lot of destiny.

Daran schliessen sich die zweisilbigen worter auf -ow. Das suffix -va in Aengl. substantivis, wie swalene, findet sich Mengl. mit nominibus und verbis auf Aengl. $-g$, $-h$, -gian zurückgehend, nach erweichung des $g$ zusammen, wie holewe, Aengl. holh (s. Stratmann, 0. E. D. ${ }^{3}$ ), folewen, Aengl. folgian. Dazu kommen andere worter, die anders entstanden, wie window, Aengl. windeage, wo die betonnng auf der zweiten silbe eigentlich weniger befremden könnte, fellow Anord. Celagi. -ewe wird zu -owe, daneben -eve mit verstummendem erstem $\mathcal{l}$ im Mengl erbalten und auch noch im 16. jh. nicht selten. Fir -owe ist die länge ausser zweifel und so fallen diese wörter in die analogie obengenannter wortgattungen

1 Dieser vers könnte auch durch verschleifung von either Atride und annahme fehlenden auftaktes wegfallen. 
mit starkem nebenaccent ( $\nabla$ gl. die versetzte betonung von feláve in King Horn, Wissmann s. 44 und auch Child bei Ellis, 0. E. E. Pr. I 369).' Die betreffenden verse sind:

4 The swift swallow pirsueth the flies smale

142 And my wife shall follow far off my steps

23 In my window, where I may see

145 Long to furrow large space of stormy seas.

Die zahl all der erwïhnten fälle wïrde noch bedentend anwachsen, wenn die trochaeen an 1. stelle and nach pausen mitgezïhlt wlirden; doch wer will entscheiden, ob der dichter einmal einen trochaens etwa durch ein holding, follow u. dgl. absichtlich zur syntaktischen markierung angewendet, oder ob ihn der tonwert der betreffenden silben daza verleitet?

3. Die zahlreichen fälle, die durch moderne betonung Roman. wörter entstïnden, wurden schon bei der besprechung der wortbetonung angefuhrt. Es sei noch bemerkt, dass es nicht unmöglich ist, dass Germanische wörter mit ausgängen auf -on, $-y$ durch falsche analogie mit Romanischen anf -on, $-y$ in ihrer betonungebenfalls alteriert wurden. Folgende verse, in denen wir freilich auch härten, wie tiberall zugeben könnten, sprechen dafir:

130 With such weapons they shope them to defend

174 She sprinkle the body, and bring the beasts

176 From this body - And when she thus had said

81 And time buried and doth revive and time again shall waste.

Weitere beispiele, insbesondere für body, liessen sich aus zeitgenössischen und früberen denkmälern leicht heranziehen.

4. Weder durch schwankende betonung, noch durch den einfluss des nebenaccents sind folgende härten zu erklären:

69 But proud people that dread not fall

70 Thy proud towers and turrets high

7 I know under the green the serpent how she lurks

80 Confess under the sun, that every thing is vain

81 Have searched long to know all things under the sun

58 God that sendeth withdraweth winter sharp

53 No thing under the sun, that 1 can hear or see

130 Of old fathers the proud and royall works

131 Whom cold winter all bolne hid under ground

132 The fray'd mothers wandring through the wide house

1 Auch der vers in Shakspere's Cymbeline IV 3. 9: 'The life of comfort. But for thee, fellow' ist characteristisch. Abbott, Shakesp.-gr. 329 fuhrt denselben als ein beispiel des sogenannten 'pause-accent' im letzten fusse an, wobei or bemerkt: "The old pronunciation "fellow" is probably not Shakespearian'. Die wahrheit liegt wol in der mitte: der fortwirkende nehenaccent anf -on gestattet das wort auf dem letzten fusse za betonen. 
139 To have lived after the city taken

142 An old temple there stands, whereas some time

142 And thou father receive into thy hands

146 A new number of males mothers and men

148 Or with thund 'r the mighty Lord me send

156 His fair mother behight him not to us

157 To the water then took he his descent

170 Or me scorned to their proud ships receive

170. And thou sister first vanquish'd with my tears

127 Each palace and sacred porch of the gods

135 Reigned over so many peoples and realms

160 What! until my brother Pygmalion

154 Of Gods begat; the last sister they write.

154 Whom our mother the earth, tempted by wrath.

Ueberblickt man die fälle der unberechtigten trochaeen, so erscheinen cinige dennoch nicht ganz als härten, so insbesondere einige fälle der anrede, wie father ${ }^{142}$, sister ${ }^{170}$. Da in solchen fragen aber der individuellen ansicht ein gar weiter spielraum gelassen ist, hielt ich es für nōtig, die lange liste der auffälligeu verse abzudrucken. Jedenfalls ist die zahl der bärten im verhältnis zu den etwa 4000 bis 5000 versen keine ubermässig grosse, wie es im vergleich uit den folgenden denkmälern vielleicht erscheineu mag. Die härten können als gelegentliche bezeichnet werden und stören nicht den eindruck eines kräftig dahinfliessenden rhythmus.

Eine andere unregelmässigkeit ist das auftreten tiberzähliger silben im verse.

Musten wir bei besprechung der trochaeen hăufig das gobiet der wortbetonung berulhren, so hängt die zulassung uberzälliger silben mit der silbenmessung der einzelnen worte vielfach zusammen. Ls ist zu unterscheiden zwischen uberzăhligen silben innerbalb des rhythmus, und solchen nach einer pause und am versschlusse. Als uberzählige silben innerhalb des rhythmus sind vor allem alle zusammenziehungen aufzufassen, von denen es wahrscheinlich ist, dass sie im zeitmass einer silbe zweisilbig ausgesprochen wurden, wie z. b. savoury, marvellous, ebenso bei zwei silben wie many a u. dgl. Sicher zweisilbig musten zwei wörter ausgesprochen werden, die kein synkopierbares $e$ enthielten oder nicht aus $i(e, u)+$ vocal bestanden.

Dass der dichter absichtlich etwa dactylon oder anapaeste anwenden wollte, scheint wir unwahrscheinlich, eine theorie 
lässt sich daraus wol nicht estwickeln. Inwiefern dadurch gelegentlich kräftigere ausdrucksweise oder ein anderes mal härte entstanden, sollen die beispiele dartun:

23 That with the spoil of my heart did go

56 The mean diet no delicate fare

70 With famine and pest lamentably

68. So fervent hot thy dissulute life

14 And Windsor alas! doth chase me from her sight!

87 End carry the rod that scourgeth them that glory in their gold

20 To banish the less, I find my chief relief

136 To revenge my town, unto such ruin brought

$15 \tilde{5}$ As mindful of ill and lies, as blasing truth

155 A woman that wandring in our coasts hath bought

107. It was the Lord that broke the bloody compacts of those.

In betreff des künstlerischen wertes solcher zweisilbigen senkungen, verweise ich auf die ausfuhrungen bei Mommsen und Schipper.

Eine frage für sich sind die tiberzähligen silben am versschlusse oder nach einer pause, die weiblichen ausgänge und caesuren.

Der weibliche versausgang gehört im ganzen zu den sèltenheiten in Surrey's metrik. Die wenigen fälle scheinen eher als ausnahmen zu bezeichnen zu sein. Sie sind folgende:

I Solomon, Davids son, king of Jerusalem

80 Chosen by God to teach the Jervs and in Tis laws to lead them (dies der einzige fall bei Surrey, eine hebung mit einer senkung zu reimen!)

Ferner mit weiblichen reim zwischen 12- und 14 silbler:

Such proofs before the just, to cause the hearts to waver

103 Be set like cups, mingled with gall, of bitter taste and savour

Oefters im blankvers.

An der fraglichen stelle: ferner:

113 _ By the divine science of Minerva,

149 Whiles winter frets the seas, and watry Orion, wenn hier nicht ein 12 silbler zu lesen, ist,

160 All utterly I could not seem forsaken

159. Doth prick her forth hearing Bacekus name hallowed

$169 \mathrm{Him}$ she requires of justice to remember.

Dazu in dem oberwahnten schlechten verse:

139 To have lived after the city taken. 
Anders steht es mit der weiblichen caesur.

Die geschichte der weiblichen eaesur im Mengl. vers ist sehr interessant. Hier sei nur bemerkt, dass nicht nur Skelton sondern auch Douglas dieselbe sehr häufig aufweisen. Ueber Skelton's verhältnis zur Howard'schen familie s. Dyce's Skeltonausgabe I, XXXIX. Douglas' Virgilubersetzung lag Surrey direct vor.

Surrey zeigt häufig weibliche caesuren, und wie wir gesehen haben, weniger weiblichen versschluss. Eigentumlich ist es freilich, dass wir die weibliche eaesur nur nach der vierten silbe haben. Prof. Mayor (Transact. of the Philol. Soc. 1875/6 s. 421) zählt in Shakspere's Macbeth 25 weibliche caesuren nach der 4. silbe und 32 nach der 6.

Bei Surrey finden sich folgende nach der vierten silbe:

Im 8-silbler:

23 When other lovers | in arms across

76 If absence quoth $I$ | be marvellous

76 To her whom unneth $\mid$ I love and shall

179 Since this to follow Tof force thou must,

welch letzterer fall vielleicht durch verschleifung von follow of wegfällt.

Im 14-silbler:

103 By wrathes children; | and from my birth | my chastising

Im gereimten 10-silbler: began.

19 So cruel prison | how could betide alas!

16 Mine eyes discover; | and to my mind resort

58 The great Macedon | that out of Persin chased.

Im blankvers weit häufiger:

131 Like to the adder | with venemous herbes fed

132 And the large palace \} with soldiers gan to fill

144 In the void porches | Phenix, Ulysses eke

147 What new guest is this | that to our realm is come?

169 The Troyan navy | and Teucrian vile commands

170 Who would me suffer | (admit this were my will).

Die drei letzten fälle könnten durch verschleifung von to our, navy and, suffer admit auch wegfallen. Ferner:

$148 O$ sister dearer $\mid$ beloved than the light

149 By Gods purveyance it blen, | and Juno's help

150 The Troies travails $\mid$ to hear a-new she lists

153 To visit Delos | his mother's mansion

154 And Venus nephen | the cottages for fear

158 Amid his throatal $\mid$ his voice likewise gan stick 
167 The ugly furies | his slaughter to revenge

171 When by her window / the queen the peeping day.

Für das mögliche vorkommen der weiblichen caesur nach der sechsten silbe spricht uur der rers:

157 With misty clouds is beaten with wind and storm, doch wăre die pause la besser nach clouds, und ausserdem beaten nach analogie andrer fälle im zeitmasse einer silbe $\mathbf{z u}$ lesen.

Aus dem angefthrteu ergibt sicb das resultat, dass der weibliche versausgang bei Surrey uur sehr vereinzelt, die weibliche caesur nach der vierten silbe aber rceht häufig vorkommt, und zwar dass der blankvers besonders die weibliche caesur häufiger als die andern versrhythmen zeigt, was vielleicht auf den einfluss von Douglas zuruckzufuhren ist.

Als dritte unregelmässigkeit im versihythmus ist die einmischung kurzerer und lăngerer verse zu bezeichnen.

Einige wenige fälle scheinen beabsichtigt, und zwar in der Virgilubersetzung dem Latein entsprechend:

115 Imagine all the rest. AEneis II 66: Disce omnes.

129 Take ye your flight. Wn. II 640: Vos agitate fugam.

149 Or yet thy brothers threats. En. IV 44: Germanique minas.

Doch ist zu bemerken, dass ausser den dreien, keinem der ubrigen verkurzten verse Virgil's auch bei Surrey einer entspricht.

Die sonstigen fălle sind wol aus versehen entstanden, wovor Gascoigne (a. a. o. s. 32-33) eindringlich warnt.

Um einen fuss $z u$ lang ist ein 10 silbler unter 8 silbler geraten.

\section{Enemies to God beat stone from stone}

Thine idols burnt, that wrought iniquity:

70 When none thy ruin shall bemoan.

Andrerseits um einen fuss zu kurz steht ein 10 silbler unter 12silblern:

106 A trembling cold of death overwhelmeth my heart, wo durch annahme arger härten in overwhelmeth und vollmessung dieses wortes der 12 silbler herzustellen wãre.

Sonst finden sich nur fälle im blankverse, wo ja wegen der mangelnden bindung des endreims sorgloser gèmessen wurde. Um einen fuss zu kurz:

138 Round hewen with axe, that husbandman 
145 Me here the Gods great mother holds

156 From Greekish arms: but such a one.

Noch häufiger um einen fuss zu lange verse:

126 As fury guided me and whereas I had heard

144 The children orderly and mothers pale for fright

und ebenso noch auf s. 148, 149, 169, 172, 173.

Diese unregelmässigkeiten, verhältnismässig nicht viele, finden sich auch bei den grossen dichtern der folgenden perioden, wie auch heute. Jedenfalls ist der rhythmus nichtsdestoweniger ein einheitlicher zu nennen, und nicht auf eine stufe mit dem der meisten dramen der zeit zu stellen.

Es erubbrigt noch, einige stellen zu erwähnen, die schlecht überliefert zu sein scheinen: Doth call her forth with noise of dancing 159 sollte ein blankvers sein; obwol man ja verschiedene versuche nach den verschiedenen freiheiten machen könnte, scheint der vers doch eher schlecht uberliefert. Ebenso der alexandriner auf s. 55: So in despair and hope plung'd am I both up and down, der aber vielleicht durch umstellung und verschleifung von $I$ am zu bessern wäre.

Anders sind einige andere fälle aufzufassen. Die verse:

62 Norfolk sprung thee, Lambeth holds thee dead

59 Some that watched with the murdrers knife

12 Love that liveth and reigneth in my thought

150 Like the stricken hind with shaft in Crete

170 Shall I wait? or board them with my power.

werden wol als solche mit fehlendem auftact, wie dies in Mengl. zeit nicht selten, zu bezeichnen sein.

Dass in die blankverse mitunter gereimte 10 silbler gekommen sind, wäre nicht zu verwundern; es ist nur ein fall zu verzeichnen, cléar : níar $(a: b: a)$ s. 142.

Alliteration scheint bei Surrey nicht beabsichtigt. Es ist interessant, was Gascoigne dartiber sagt (a. a. o. s. 36):

You may use the same Figures or Tropes in verse which are used in prose, and in my iudgement they serve more aptly, and have greater grace in verse than they have in prose: but yet therein remembre this old adage 'Ne quid nimis', as many wryters which do know the use of any other figure than that whiche is expressed in repeticion of sundrie wordes beginning all with one letter, the whiche (beyng modestly used) lendeth good grace to a verse: but they do so hunte a letter to death, that they make it crambé, and crambe bis positum mors est: therefore 'Ne quid nimis'. 
Dies ist die anschaung der neuen kunstpoesie uber die alliteration. Verse wie:

$$
\begin{aligned}
& 130 \text { A fight of rage and fury there we san oder } \\
& 131 \text { But soon another sort stept in their stead }
\end{aligned}
$$

beweisen gerade nicht viel, da sie selten sind.

Aus dem etwas abgestumpften gefuhl fur den rhythmus ist es zu erklären, dass, abgesehen von den obenerwăhnten härten, man sich nicht scheute, logisch wenig betonte einsilbige worte in die hebung zu setzen. Es kommt das naturlich bei allen dichtern bis zu einem gewissen grade vor, und fällt selten auf, da ja nicht alle hebungen in der declamation gleichwertig sind. Ein geschickter vorleser wird daruber anstandslos hinweglesen können, und zwar jedenfalls viel leichter als bei mehrsilbigen, wichtigeren wörtern, weshalb deren incorrecte verwendung im verse nicht auf derselben stufe steht, wie die von the, of, to u. dgl.

Surrey zeigt dergleichen wiederholt, z. b.:

Than to boast of such perfectness, whose works such fraud express oder:

124 From the high rock while he doth hear the sound u. a. m.

Was den blankvers besonders für epische, didactische und dramatische dichtung so beliebt machen muste, war eben die freiheit und unabhängigkeit einer verszeile von der andern, die es ermōglichte, je nach bedarf uber die funf füsse hinaus einen gedanken fortzuspinnen, wenn nur uberhaupt der rhythmus gewahrt blieb. Das enjambement, die grössern satzpunkte im innern des verses, sind der stolz des Englischen blankverses in seiner höhe, so bei Milton. In wie weit sich dies in den uns hier zunăchst betreffenden denkmalem zeigt, soll taberall eine probe veranschaulichen. Fur Surrey fuge ich noch ein stuck in gereimten funffussigen jamben hinzu, zur vergleichung:

Description and praise of his love Geraldine.

From Tuscane came my Lady's worthy race;

Fair Florence was sometime her ancient seat:

The western isle, whose pleasant shore doth face

Wild Camber's cliffs, did give her lively heat:

Foster'd she was with milk of lrish breast:

Her sire an Earl, her dame of Princes blood.

From tender years, in Britain she doth rest,

With kinges child; where she tasteth costly food. 
Hunsdon did first present her to mine eyen:

Bright is her hue, and Geraldine she hight.

Hampton me taught to wish her first for mine;

And Windsor, alas! doth chase me from her sight.

Her beauty of kind; her virtues from above;

Happy is he that can obtain her love!

Aus dem 4. buche der Aeneide:

$O$ sister! if so great a sorron $I$

Mistrusted had, it were more light to bear.

Yet natheless this for me wretched wight, Anne, shalt thou do: for faitheless, thee alone

He reverenced, thee eke his secrets told; - -

- So was this Lord now here now there beset

With words; in whose stout breast wrought many cares.

But still his mind in one remains; in vain

The tears were shed. - etc. etc.

In dem blankverse Surrey's haben wir also folgendes zu erkennen:

Der jambische rhythmus erscheint einerseits absichtlich unterbrochen, andrerseits finden sich gewisse wortarten, sowie aber auch einzelneworte, so im verse verwendet, dass gelegentliche härten entstehen. Die betreffenden wortarten rechtfertigen sich $z u m$ teil durch die verwendung, die sie im Mengl. verse hatten, sind also als ein therrest der Mengl. periode anzusehen. Dazu kommen noch andere Mengl. aberbleibsel, wie das fehlen des auftacts in einigen fällen. Im ganzen muss man aber auch den einfluss des silbenzăhlenden prinzips der Romanischen metrik noch als wirksam gelten lassen. Die erscheinung, dass häufig mehrere silben an der stelle von zweien stehen, ist der Mengl. wie der Nengl. zeit bis auf den heutigen tag eigen, und ist oft recht wirkungsvoll. Stellenweise dactylischen oder anapaestischen rhythmus dafur anzusetzen, ist unnötig. Die weiblichen caesuren sind ebenfalls ein uberbleibsel aus Mengl. zeit. Alliteration spielt keine rolle.

Bei den folgenden denkmälern kann ich mich kürzer fassen. In den der zeit nach zunächst liegenden $z$ wei gedichten von Nicholas Grimoald ist schon ein entschiedener fortschritt gegenuber Surrey zu bemerken. 
Silbenmessung und wortbetonung bieten wenig auffälliges. Die $e$-haltenden endungen sind im ganzen öfter uubetont als bei Surrey, an kräftigen zusammenziehungen fehlt es nicht, so - ich citiere nach der seitenzahl in Arber's reprint der Tottel'schen sammlung - clattering ${ }^{120}$, heauen ${ }^{121}$, desperately ${ }^{21}$, wie andrerseits nicht an gelegentlich wirkungsvollen vollmessungen, wie in dem rerse:

122 So, that the blood down reyled on the ground.

Romanische ableitungssilben mit $i(e, u)+$ vocal sind meist contrahiert: sapience ${ }^{122}$, Macedonians ${ }^{122}$, oblivion ${ }^{121}$, constellation ${ }^{122}$, victorious ${ }^{134}$, presumptuous $\overline{125}$, Cassius ${ }^{124},{ }^{-}$Antonius $\overline{123}, \overline{\text { jedoch }}$ Tullius am versende. Synaloephe in th'armed ${ }^{124}$.

Von Romanischer wortbetonung findet sich noch image $^{124}$ einmal durch den versschluss verbürgt. Die möglicherweise schwankenden betonungen German. composita, die ich bei Surrey, soweit sie im versinnern waren, bei besprechung des versrhythmus behandelt habe, werde ich in zukunft aus praktischen grinden bei der wortbetonung anfuhren.

Am versschlusse finden sich keine beispiele, wol aber im versinnern:

121 In the primetide dothe season well the soyle

125 That flowing toung when his windp ype disclosde

124 And Jove desires a new heavensman to make

122 Him to forbear set spurrs unto his steed.

Die fălle sind um so wahrscheinlicher als schwankende betonungen zu bezeichnen, als der versrhythmus den grossen fortschritt gegentiber Surrey zeigt, dass sich keinerlei sogenannten härten mehr finden.

Belebt ist der rhythmus gelegentlich durch wirkungsvolle trochaeen. An erster stelle:

120 Shrowded with shafts, the heven: with clowd of darts oder

124 Neither shall we perchaunce dye unrevenged

und noch etwa zwölf fälle.

An dritter stelle nach der pause ein einziger fall:

123 Perdie these thanks, reskued from civil swoord.

Von tuberzähligen silben findet sich nur ein weiblicher versausgang:

125 Swaps of the hed, with his presumpluous yron

Dass sich einmal ein reim prouokes : strokes ${ }^{121}(\mathrm{a}: \mathrm{b}: \mathrm{a})$ findet, kann zufall sein. 
Alliteration scheint an einigen stellen unleugbar zum schmucke des verses angewendet zu sein:

125 Dastards, why stand you styll: he sayth: and streight

121 Or him more mylde what opposition markes

121 Apolloes laurel, both for learnings laude

121 A match more meet, sir king, than any here u. a.m.

Zur veranschaulichung des rhythmus, enjambement u. dgl. eine probe:

The noble prince amoued, takes ruthe upon

The wilfull wight: and, with soft woords, ayen,

() monstrous man, (quod he) whatso thou art,

I praye thee, lyue: ne do not, with thy death

This lodge of lore, the Muses mansion marr u.s.w.

Auch die ubrigen in T'ottel's sammlung abgedruckten dichtungen Grimoald's in 10 silblern zeigen klar, dass wir es mit einem dichter zu tun haben, der durch die neue kunstschule gegangen. Wahrung der Englischen betonungsgesetze, vermeiden von schleppenden vollmessungen, grosse reinheit, dabei aber lebendigkeit des rhythmus, keine weiblichen caesuren.

Surrey's Virgiltabertragung und die wenigen verse Grimoald's sind die einzigen denkmäler im blankvers, bevor derselbe im drama angewendet wurde. 1561 zur weihnachtsfeier ward Gorboduc im Inner-Temple aufyefuhrt. Man bezeichnet als verfasser 'Thomas Norton und Thomas Sackville Lord Buckehurst. Norton soll die drei ersten acte, Sackville den vierten und funften geschrieben haben. Warton (Hist. of E. P. IV 265) spricht sich gegen diese annabme aus und will von einer teilnahme Norton's nichts wissen. In wieweit sich in metrischer hinsicht zwischen den ersten drei acten und den zwei letzten unterschiede ergeben, wird die einzelbetrachtung zeigen. Ich habe nur die ausgabe in Dodsley's collection von 1780, band 1., zur hand, welche ein abdruck der ersten autorisierten ausgabe von 1571 ist, und citiere nach der seitenzahl daselbst. Der 3. act reicht bis s. 138, der 4. act beginnt s. 139. Ich nenne act $1-3 \mathrm{~A}, 4-5 \mathrm{~B}$.

Silbenmessung.

Hinsichtlich der endungen ist nichts zu bemerken, es verhălt sich damit wie bei Surrey und durch das ganze stuck gleich. 
Allerdings ist dic vollmessung in A häufiger, ja zuweilen unschön:

111 Hath firmely fixed his unmoved mind

125 Ne yet he wrongeth you that geveth you.

Die zusammenziehungen nach $v$ und vor $r$ sind in A und B auf gleicher stufe: heauen ${ }^{124 \cdot 138}$ u. ö., even ${ }^{111}$, soveraigne ${ }^{113 .}{ }^{114}$ u. .0 ., murderous ${ }^{138}$, temperates 124 neben reverence $\overline{129}^{129}$, heauen ${ }^{111}$. 128. ${ }^{138}$, sufferance ${ }^{152}$, wavering ${ }^{153}$, power ${ }^{153 .}{ }^{163}$ neben difference ${ }^{157}$, powers ${ }^{159}$, dangerous 157 u. a. $\mathrm{m}$. Bei anderen consonanten: poysonous ${ }^{113}$.

Vocalische zusammenziehungen: envious ${ }^{111}$, ambitious ${ }^{111}$, vertuous $^{117}$, region ${ }^{117}$, ambition ${ }^{121}$, keine vollmessungen. Ëbenso in $\mathrm{B}$ krasis in violent ${ }^{128}$. likelihode ${ }^{125}$ ist $\mathrm{wol}$ wie $\mathrm{z}$. b. livelode bei Wiat (Yeowell's ausg. s. 186) aufufassen.

B zeigt ferner synaloephe oder synhaerese: body of ${ }^{159}$, thou art ${ }^{142}$, to adventure ${ }^{155}$, to imbrace ${ }^{158}$, worthy $a^{1 \overline{49}}$.

Wortbetonung.

Romanische betonungen vereinzelt:

112 Murders, mischief, or civill sword at length, mit mehr wahrscheinlichkeit in

132 Ere this mischiefe come to the likely end

143 For true recorde of this my faithful speche

140 Of their entrailes to staine thy deadly handes

156 What blind fury thus headlong caries them, doch sonst ist durchaus der Englische ton durchgedrungen, in zahllosen fällen von mischief, recorde ${ }^{147}$, travail 114. 122. 158, silence ${ }^{129}$, torment ${ }^{124 \cdot 143}$, tumult ${ }^{153}$ u. s. w.; maintain ${ }^{127}$ wie heute. $\overline{\mathrm{Zu}}$ weit zurückgezogener ton in:

160 Of present wealth and noblesse of your stockes.

Schwankende betonungen Germanischer composita finden sich mehrmals durch den versschluss verburgt. Zweimal also ${ }^{120.161}$, uproares ${ }^{155}$, uproare ${ }^{153}$. Im versinnern, wo wir ja härten annehmen können, die durch derlei wörter leichter als sonst $\mathrm{zu}$ entschuldigen wären:

137 From feble faintenesse of bootelesse despeire

157 With mindes hopelesse of life, dreadlesse of death

157 Carelesse of countrey and awelesse of God

113 And myne also doth aske an other chaunge

152 Wherby how some kingdomes of mightie power

152 Than sufferance of up roares without redresse

151 A new bloudshod unto the princes' kinne 
161 Unnaturall thraldome of strongers reigne

111 True sayth to my for efathers; and their seede

117 Three noble sonnes of your for efather Brute

of thy for efathers, when the cruell sworde.

Das wörtchen unto verhält sich wie bei Surrey. Wir können, wenn wir die gegenwärtige betonung aufrecht erhalten, einige trochaeen, wo sie nicht unberechtigt wären, herauszählen, desgleichen den dichtern mehrere bärten zuschreiben, was aber doch bei dem geringen nachdruck der auf einer praeposition meist liegt, und bei der erwiesen schwankenden betonung dieses wortes in damaliger zeit, $\mathrm{zu}$ weit hergeholt wäre. In der betonung der eigennamen herscht auch im Gorboduc regellosigkeit. Hauptsächlich die namen von Ferrex und Porrex finden sich beständig abwechselnd, oft kurz hintereinander, jambisch und trochaeisch betont, und zwar in $\mathbf{A}$ und in $B$.

Die wortbetonung zeigt uns keinen besonderen unterschied zwischen dem 1., 2., 3. und dem 4., 5. acte.

Versihythmus.

Der streng jambische versgang zeigt gleich in den ersten i drei zeilen schönen wechsel in den pausen:

The silent night | that bringes the quiet pawse,

From painefull travailes $\mid$ of the wearie day,

Prolonges my carefull thoughtes | and makes me blame.

Trochaeen finden sich am versanfange sehr häufig:

112 Guiding so great estate with great renowme oder

143 Melting in teares within a manly brest

und ebenso blos rhetorisch:

130 Warre would he have? and he shall have it so oder

156 Ours is the sceptre then of Great Brilagne.

Die anzahl der fälle ist in A ungefähr gleich der in B.

Wirkungsvolle trochaeen nach der pause, und zwar nur an dritter stelle, sind häufig.

In $\mathrm{A}$ :

128 Commaund, thefles, rapes | murder of innocents

.137 Wisdome or force, | counsell or Knightly aide,

ausserdem im gereimten chor:

133 Loe, thus it is I poyson in golde to take

Weit häufiger in $B$ :

140 Wherein my hart | yelden to death is graved oder

141 Ruthelesse unkind|monster of natures worke, 
desgleichen auf s. 146, 148, 149, 154, 155, 156, 158, 159, 163. Härten finden sich sehr wenige, wenn man von den fraglichen fällen schwankender betonungen, die bereits aufgezählt wurden, absieht.

In $\mathrm{A}$ :

121 The younger a yelding contentednesse,

129 With whom, neither one only brother deare,

welch letzterer fall durch annahme einer pause nach whom gar nicht schlecht klänge.

In B finde ich keine härte, uber den vers Our wives children kindred ourselves and all ${ }^{159} \mathrm{vgl}$. das bei der weiblichen caesur gesagte.

Natürlich sind rhetorische trochaeen an keine regel gebunden, z. b.:

The end? Thy end 1 feare: Jove end me first, wodurch der jambische rhythmus aber gar nicht alteriert zu werden braucht.

Ueberzählige silben.

In den raum eines fusses finden sich ausser in den schon besprochenen contractionen und verschleifungen, selten mehr als zwei silben gedrängt, nur in $\mathbf{A}$ :

119 But long may they learne ere they begyn to rule.

Weiblicher versausgang findet sich nur in B dreimal:

149 And that most cruell hand the wretched weapon

162 With five and sworde thy native folke shall perishe

163 No, no: then parliament should have been holden.

Weibliche caesur findet sich einmal in A und einmal in B:

109 The slowe Aurora|that so for love and shame und

159 Our wives children | kindred ourselves and all,

wobei ich es nänlich vorziehe wives vollzumessen, anstatt eine störende härte in children zuzulassen. Uebrigens sind die fälle von weiblichen ausgängen so selten, dass sie als zufällig aufzufassen sind.

Einmischung kurzerer und längerer verse.

Woll aus versehen findet sich in den blankversen in $A$ ein 8silbler:

114 Shen forth such meanes of circumstance

und in A und B je ein 12 silbler:

1380 king the greatest griefe, that ever prince dyd heare und

159 Even of the learned sort and more uncertainly. 
Der vermutlich schlecht dberlieferte vers in B: The guiltlesse king without desert all ist vielleicht durch einschiebung eines at vor all zu bessern.

Feblender auftact ist wol anzunehmen in den versen: Yelde large roume unto their growing rage ${ }^{137}$, wenn nicht targer $\mathrm{zu}$ lesen ist, und Since 1 may not shewe my smallest grief ${ }^{143}$.

Mituntergelaufene reime finden sich nicht, auch keine alliteration.

Interessant ist, dass zur belebung des verses nicht nur satzpuncte von einem verse in die mitte des folgenden tabertragen werden, sondern dass auch zuweilen rede und gegenrede den vers teilt, welcher kunstgriff, wenn nicht ubertrieben, sehr wirkungsvoll ist. Z. b.:

Ferrex. To whom? oder:

Videna. Even to Porrex his yonger sonne (111).

Porrex. ... For graunt of life.

Gorboduc. In vaine, $O$ wretch thou shewest

...A woful hart; Ferrex now lyes in grave, Slayne by thy hand.

Porrex. Yet this, o father, heare (144).

und so noch auf s. 135, 148, 151/52, also bei A und B.

Im Gorboduc haben wir also eine tragödie, die in metrischer gestalt schon ganz ebenmässig und lebendig fliessend gebaut ist, die sich ganz und gar unterscheidet von den ubrigen gleichzeitigen dramen. Sie ward so in jeder hinsicht von bedeutendem einfluss auf die weiterentwicklung des Englischen dramas.

Die unterschiede zwischen den vermutlichen zwei autoren sind nicht sehr gross und können im einzelnen auf zufälligkeiten beruben, obwol sich die erscheinung der weit häufigern trochaeen in B nicht unterschätzen lässt. Eine probe aus beiden teilen wird willkommen sein.

Aus dem 1. act:

Your good acceptance so (most noble king)

Of such our faithfulnesse, as heretofore

We have employed in dueties to your grace

And to this realme whose worthy head you are,

Well proves that neyther you mistrust at all, Nor we shall neede in boasting wise to sheve Our trueth to you, nor yet our wakefull care For you, for yours, and for our native land. 
Aús dem 5. act:

1s this his faith? and shall he falsely thus Abuse the vauntage of unhappie times? 0 wretched land, if his outragious pride, His cruell and untempred wilfulnesse, His deepe dissembling, sherves of false pretence, Should once altaine the cromne of Brittaine land Let us, my lordes, with timely force resist The new attempt of this our common foe As we would quench the flame of common fire.

Dem Gorboduc folgte 1566 das zweite drama in blankversen, die thersetzung der Phönizierinnen des Euripides, 'Jocasta' von George Gascoigne und Francis Kinwelmarshe.

Kinwelmarshe schrieb den 1. und 4. act, Gascoigne den 2., 3. und 5. Die chöre sprechen zum schlusse der acte in gereimten 10 silblern, ebenso ist der epilog von $\mathrm{Chr}$. Yelverton abgefasst.

Da ther die autorschaft Kinwelmarshe's und Gascoigne's kein zweifel vorliegt, so ist die frage nach metrischen unterschieden nicht so wichtig. Ich citiere nach der seitenzahl in der Hazlitt'schen ausgabe der werke Gascoigne's für die Roxburghe Library 1869, wo das stuck bd. I s. $257-349$ steht. Act I reicht bis 8. 275. Act IV von 8. $315-328$.

Silbenmessung.

Die endungen in der regel unbetont, werden doch bäufig vollgemessen, wenn der vers es erheischt, und zwar im versinnern wie am schlusse: neben mightest ${ }^{282}$,hăufig knowest ${ }^{303}$, seemest ${ }^{306}$, wouldest ${ }^{306}$, wayeth ${ }^{267}$, $\overline{\text { |ried }}{ }^{285}$, undisguised ${ }^{265}$, unburied ${ }^{342}$, for decreed ${ }^{345}, \overline{\text { decreed }}^{373}$, stayed $^{324}$, given ${ }^{200}$, fallen ${ }^{303}$, swollen 321 neben borne $e^{332}$ u. dgl. $\mathrm{m}$.

Ein betontes endungs - $e$ ist vielleicht anzunehmen in dem verse: Go to the lande of Thesprotia ${ }^{311}$.

Romanische ableitungssilben, die mil $i(e, u)+$ vocal anlauten, zeigen sich in der regel contrahiert und nur a m versschlusse vollgemessen: marriage 260. 281. 297, ancient ${ }^{260}$, suspicion ${ }^{262}$, dungeon ${ }^{267}$, experience ${ }^{262.325}$, precious ${ }^{262}$ u. a. m., wăhrend am versschlusse marriage ${ }^{282}$, possession ${ }^{287}$, ambition ${ }^{288}$ ${ }^{290}$, experience ${ }^{290}$.

Diese falle der vollmessung am versschlusse finden sich 
nur bei G., der auch noch im innern, allerdings vor einer pause, marriage ${ }^{342}$ und pacience ${ }^{346}$ bietet. Krasis steht in cruell ${ }^{332}$, quiet ${ }^{290}$. Ueberhaupt sind kräftige zusammenziehungen nicht selten, so:

K. heaven ${ }^{262 \cdot 263}$, even ${ }^{266}$, ever ${ }^{271}$, seven ${ }^{272}$, euill ${ }^{271 \cdot 273}$, towers ${ }^{267}$, murdering ${ }^{263}$, conquering ${ }^{263}$, glittering ${ }^{263}$, slaunderous ${ }^{273}$, threatning ${ }^{267}$, enmie $\overline{269}$, doch auch earnestly 271 .

G. leven ${ }^{297}$, even ${ }^{286}$, ever $y^{286}, T_{\text {to }}$ pour ${ }^{289}$, exilles ${ }^{291 \cdot 307}$, diuelish ${ }^{292}$, enimies ${ }^{305}$ neben reverence am versschlusse und ebenso enemie ${ }^{2 \overline{y 3}}$, earnest. spirit scheint in der regel einsilbig gesprochen worden zu sein. Verschleifung zweier wörter: mother and ${ }^{335}$.

Die eigennamen sind auch hier schwankend: Tydeus ${ }^{282.283}$, Tyresias ${ }^{298}$, Thebes ${ }^{261 \cdot 28}$ neben Thebes ${ }^{265 \cdot 266}$, Eteocles ${ }^{265 \cdot}{ }^{283}$, neben Eteocles 321.

Wortbetonung.

Grobe verletzungen des Germanischen betonungsgesetzes und zwar am versschlusse wären in einigen fällen anzusetzen, wenn wir nicht ein end- $e$ betonen und dann weiblichen versausgang annehmen:

G. 303 Bringing with him the pure and faire offrings

277 The traine of Jocasta, my deare mother

346 Ismene my infortunate sister

K. 261 Than that renoumed prince your deare father.

Desgleichen fällt der vers bei G.: $O$ Jocasta, miserable mother ${ }^{331}$ durch seine härte auf; doch durch einsetzung eines zweiten 0 ! vor miserable oder durch annahme eines feblenden auftakts wäre derselbe hergestellt.

Von resten Romanischer betonung finden sich folgende:

K. 319 Of which conflicte the ende must needes be this

2i.1 And olde recordes of auncient time long since

G. 345 In this exile to be my woful mate

345 I am exilde farre from my countrey soyle

277 And that from him the safeconduct is given

307 For his countrey: lo! heere is all you seeke

330 To his countrey, and yet a cruell foe

277 Loe, here mine onne citic and natiue soyle

2930 dear citie. When thou arivest in Greece

299 And doth envie the pleasant merry moode

(Degl. im epilog Yelverton's:

349 They not envic the pompe of haughtie traine) 
284 Thine owne image, remember there withall.

Ferner:

268 From that outrage and fierce repyning wrathe

321 Of this outrage thou only art the cause.

K. 322 You a weake old woman forworne with yeares und

2670 princes, how for themselves they raigne not,

wozu Abbott s. 394 ff. zu vergleichen ist.

Daneben natülich in der regel die Romanischen wörter nach Engl. betonung in thereinstimmung mit dem versrhythmus: K. discord (subst.) ${ }^{263}$, desert (adj.) ${ }^{261}$, mervayle (subst.) 263. 266, captive $^{318}$, mischief ${ }^{318}$, image ${ }^{321} ;$ G. exile ${ }^{\overline{343}}$, citie $^{297}$, image ${ }^{277}$. 339. 345 , damage ${ }^{288}$, torment (subst.) ${ }^{311}$ neben torment (verb) ${ }^{338}$ u. a. $\mathbf{m}$.

$\mathrm{Zu}$ weit zuruckgezogenen ton wird man annehmen in:

307 Hath ordeined once, and needes it must ensue (und

347 And every one that is desirous

im gereimten letzten chor).

Schwankende betonung von compositen wird vielleicht in folgenden versen anzunehmen sein; bei G.:

286 And that causlesse he holdes me from my owne

und durch den versschluss verburgt:

305 Save, loe, I finde but onely one hartstring

sowie möglicherweise:

332 Moved therto by the wicked wedlock,

wo aber auch wegen der sonstigen härten vielleicht eine zerdehnung von wedlock zu wed-lock auzunebmen ist.

Es ist wol kaum nōtig, dem causlesse ${ }^{286}$ eine reihe von beispielen desselben oder älnnlicher wörter entgegenzustellen, die die heutige betonung zeigen, wie causlesse ${ }^{285}$, recklesse ${ }^{288}$, guiltlesse $^{277}$, trustlesse ${ }^{279.208}$ u. a. m. Auf unto gehe ich hier nicht mehr ein.

Die e igennamon schwanken auch hier, z. b.: Polynices ${ }^{292.295}$ und Polynices ${ }^{297 \cdot}{ }^{298}$, Jocasta ${ }^{343}$ und Jocusta ${ }^{271}$ u. u. a. m.

Versihythmus.

Trochaeen für Jamben finden sich wiederholt, am hăufigsten an erster stelle.

Bei G. etwa 24 fălle, z. b.: Brotherly duetie to Eteocles ${ }^{286}$, ausserdem rhetorische fälle, z. b.: Pray to the Gods in Greece and not in Thebes ${ }^{292}$. Bei K. etwa 12 fălle, z. b.: Seyng this 
towne, seing my fleshe and bloude 260 , und rhetorische fälle, z. b.: Him doubt I more than any danger else 271.

Wirkungsvolle trochaeen finden sich häufig an drittér stelle nach der pause. Bei Gascoigne: O worthie dames! heavie, unhappie ye ${ }^{2 i \tau}$, ausserdem noch 10 fälle. Ebenso wie in dem verse: Where be my sweete sister? Et. And canst thou yet ${ }^{293}$, wo dem betreffenden worte keine pause vorhergeht, keine härte anzunehmen nötig ist, wegen des nachdrucks, der auf sister. liegt, findet sich ein trochaous an zweiter stelle in folgenden versen: And you, mother ${ }^{202}$ - der vers vom gegenredner vollendet,

2930 dear mother, the depth of your good will

312 Behold, father, 1 goe. You dames of Thebes

331 Bewayle, ladies, alas, good ladies, waile.

Kinwelmarshe bietet weniger trochaeen. An dritter stelle nach der pause nur: Seyng this towne / seing my fleshe and bloude 260 und noch zwei fälle. Ohne pause vorber, wegen des nachdrucks, an vierter stelle: Antigone my swete daughter come forth ${ }^{321}$, und ebenso im gereinten chor: Of Oedipus and his princely race! ${ }^{323}$.

Desgleichen an zweiter stelle zwei solche fălle:

321 Ah, swete mother! ah my beloved mother

3210 deare daughter, thy most unhappie brethren.

Durch mitzählung des end-e in swete und deare und annahme weiblicher caesur künnten beide verse anders aufgefasst werden.

Doch alle diese auskunftsmittel scheinen etwas weit hergeholt (und auch die obenerwähnten verse mit offrings, mother, sister, father in letzten fusse sind doch nicht sicher zu rechtfertigen), zumal da es an ganz ăhnlichen härten nicht fehlt, bei denen man kaum von beabsichtigtem innehalten im rhythmus sprechen kann.

Abgesclien von den fraglichen fällen, die bei der wortbetonung besprochen wurden, finden sich folgende härten. Bei Gascoigne nicht viele, sicher nur eine:

296 A Greek prisner is come unto my hands.

Mehr zeigt Kinwelmarshe, abgesehen von den oben erwähnten, noch folgende:

265 Of th'unbridled mindes of ambicious men

265 The two brethren, nay rather cruel foes

268 My dear brother, is oncly cause hereof. 
Ueberzăhlige silben.

Ausser den contractionen, die eventuell zweisilbig gelesen werden können, sind im versinnern therzählige silben nicht anzunehmen, ausser etwa in dem verse bei $K .:$

$2 i 1$ Of Creon my mothers brother appaules me much, wo brother und appaules leicht verschleifbar sind.

Weiblicher versausgang findet sich gleichmassig bei $G$. und $K$. und $\mathrm{zwar}$ nicht selten. Ausser den fraglichen, schon erwăhnten fällen auf s. 261, 277, 303, 331, 346 noeb die folgenden bei $\mathbf{~}$.:

278 But as a stranger now I thank my brother, ebenso mit den worten: inhabite 279 , (euill 280.331.332, das auch einsilbig sein kann), hither ${ }^{284}$, citie ${ }^{297}$, ceremonyes ${ }^{304}$, encounter $^{333}$, shivers ${ }^{333}$, togither ${ }^{345}$, father ${ }^{345}$.

Bei K.:

319 Tell it, I say on payne of our displeasure, ebenso mit den worten: mother 265. 271. 321, brethren ${ }^{321}$, treason $^{324}$, prison ${ }^{264}$, promise ${ }^{266}$, brother ${ }^{269}$, sister ${ }^{271}$, honor ${ }^{273}$ und ein selbständiges wort: doe it $\overline{271}$.

Weiblich e caesur bietet nur Kinwelmarshe an drei stellen:

321 Alas! what say you? | alas what do you say, hier wieder ein selbstanndiges wort, und dann mit dem worte brother ${ }^{269}$, sowie im gereimten chor: mit Phoebus ${ }^{274}$.

Einmischung kürerer und längerer verse.

Durch zufall wird bei Kinwelmarshe ein 12silbler in die blankverse geraten sein:

318 But rather Eteocles presuming too too much.

Mangelhafte vorse andrer art, wol durch sehlechte uberlieferung so geworden, bietet Gascoigne:

308 Go daughter, go; oh what foole is he

332 First Polynice, turning toward Greece.

Im ersten verse wăre ein a vor foole leicht zu ergănzen, im zweiten leicht Polynices zu schreiben. Durch annahme eines fehlenden auftaktes vor dem zweiten halbverse wären beide conjecturen tuberflussig.

Verktirzte oder unvollstăndige verse finden sich mehrfach. Einerseits zum schlusse einer rede, bei G. und K.: To trappe him in ${ }^{270}$, ebenso 8. 317. To goe to Grece ${ }^{282}$, ebenso s. 311, 330, 344. 
Andrerseits aber inmitten einer rede, gewöhnlich aber doch eine grössere pause bezeichnend, bei G. und $\mathrm{K}:$ : Thus sayde: ${ }^{330}$ ebenso Falling betweene hir sonnes ${ }^{336}$, oder ein ausruf: And out, alas for mee! !377 $^{33}$ tell the yll ${ }^{319}$ oder From whence ye came ${ }^{325}$, wo der gegenredncr auf diese worte hin abgegangen, und der folgende monolog als neue scene fur sich angesehen werden kann.

Der reim zeigt hier schon interessanteres.

Ausser zufälligen reimen bei K. wight : right ${ }^{268}$ (a:a), bei G. encrease : cease ${ }^{279}(\mathrm{a}: \mathrm{a})$, influme : same ${ }^{284}$, offenbar beabsichtigt bei G. und sehr wirkungsvoll in dem schönen bekenntnis:

$U$ mother deare, fayrer ne wyser dame

283 Is none in Greece, Argia is hir name, sowie in der schlussrede des Oedipus vor der letzten rede des chores am ende des 5 acts:

Since every man must beare with quiet minde

347 The fate that heauens haue earst to him assignde.

Alliteration fällt nicht auf, obwol sich ja manche falle finden lassen, besonders bei Kinwelmarshe, z. b.:

270 As both my brethren be, so both 1 beare

317 Senerde the Dukes into seven several partes

Das teilen eines verses unter mehrere redner zeigt Gascoigne häufig, z. b.:

293 Jocasta: O sonne. Eteocles.: Away, I say, out of these walls,

oder s. 293, wo Eteocles seinem bruder das wort abschneidet:

Pol.: And you mother. Eteocl.: Have done: thou not deservest,

ebenso noch s. 292, 293 öfters, 296, 306; im letztgenannten falle wird der vers sogar zweimal geteilt:

Tyr.: By force. Cr.: Why sleest thou! Tyr.: Sir, tis not from thee.

ferner 306 öfters, 307 u. 0 .

Bei Kinwelmarshe nur ein fall:

316 Nunt.: The Gods forbid! Joc.: Our souldiers, then perchance.

Verhältnismässig selten finden sich grössere satzpunkte im versinnern, was vielleicht im zusammenhange steht mit den unvollständigen versen bei $G$. wie bei $\mathbf{K}$.

Im allgemeinen kann man gerade nicht sagen, dass sich viel fortschritt dem Gorboduc gegenulber in der Jocasta zeigt. 
Der versrhythmus zeigt weniger ebenmässigen fluss; interessant ist der reim am schlusse von Oedipus' letzter rede.

Auch hier wird eine probe von beiden dichtern der veranschaulichung dienen.

Aus dem II. act:

Adrastus sware that he woulde soone restore

Unto our right both Tydeus and me:

And fyrst for mee that had the greater neede;

Wherhy the best and boldest blouds in Greece

Have followed me unto this enterpryse,

$A$ thing both just and grievous unto me,

Grievous I saye, for that 1 doe lament

To be constrayned by such open wrong

To warre agaynst myne onne deare countrey feeres.

But unlo you (O mother) dothe pertain

To stinte this stryfe, and both deliver mee

From exile now and eke the towne from siege: etc.

Aus dem IV. act:

Our woful wordes, our prayers and our plaintes,

Pourde out with streames of overflowing teares,

Where nature rules, may happen to prevayle,

When reason, power and force of armes do fayle.

But if the glowing heate of boyling wrath

So furious be, as it may no relent,

Then I atwixt them both will throw my selfe,

And this my brest shal beare the deadly blowes,

That otherwise should light upon my sonnes etc.

Chronologisch zunächst folgen nun die blankverse von 'Turbervile, in seiner ubersetzung der episteln Ovid's (die 11., 12., 13., 14., 20. 'und 21.). Da Collier in seinem 'Account of the rarest books etc.' s. $70 \mathrm{ff}$. zwei proben abgedruckt hat, ist es mir möglich, darauf einzugehen.

So viel man aus dem kleinen stückchen ersehen kann, zeigt die silbenmessung kräftige contractionen: teares, wordes, garments, vermilion, monstruous, marriage. Ein unterschied zwischen adjectivisch gebrauchtem participium perfecti schwacher verba und gleichartigen formen verbalen gebrauchs lässt sich hier erkennen: wir haben: fixed faith, ingaged faith, gegentiber $I$ represt; uttered, 1 was releast u. a. m. Doch daneben für beide arten volle und contrahierte formen, so dass man auch bier nicht entschieden dem adjectivischen particip grösseren ton- 
wert der endungssilbe beimessen kann, obwol dies freilich im allgemeinen sehr wahrscheinlich ist.

Die w ortbetonung bietet nichts bemerkenswertes.

Der versrbythmus ist schr glatt und lobenswert. Es findet sich nur ein trochaeus an erster stelle:

Marriage and plighted troth, no crime, 1 crave Dazu zwei rhetorische:

Death stood before my face, Lucina quile

Read and survey my lines: so may this griefe.

Ueberzählige silben finden sich nicht, weder reim noch alliteration. Das stück hat für unsern zweck nur insofern wert, als wir darin einerseits sehen, wie mit dem blankverse fortwährend gleichsam schüchterne versuche gemacht wurden, meist mitten unter gereimten 10 silblern, andrerseits aber, wie zu der zeit der rhythmische fluss in der Englischen metrik schon zu hause war, wie dies auch die probe des gereimten 10 silblers Turbervile's bei Collier a. a. o. zeigt.

Zur veranschaulichung der geschickten benutzung der freiheiten, die der blankvers gibt, auch hier einige verse:

Let hope reduce thy force, that brothers spouse

Shalt be, and wife to him by whom thou art

$A$ mother made. In faith, I was revivde

At those thy cheereful words, that lay astraught,

And was releast of griefe and gylt at once.

Entsprechend bei Ovid:

Spes bona det vires. Fratri nam nupta futura es.

Illius de quo mater, et uxor eris.

Mortua - crede mihi - tamen ad tua verba revixi:

Et positum est uteri crimen onusque mei.

Vielleicht hiermit im zusammenhang stehen die versuche Spenser's 1569. Die frage nach einer freundschaftlichen beziehung zwischen 'Turbervile und dem jungen Spenser wurde wiederholt discutiert (vgl. Spenser, ed. Morris, Globe edition s. XIX, 699), und es wäre ja nicht unmöglich, dass, wie Collier a. a. o. s. 70 annimmt, die merkwurdige vereinzelte erscheinung von blankversdichtungen in den jahren gerade bei Turbervile und Spenser auf gemeinsame dichterische bestrebungen der beiden zurtickzufüren wäre. Der umstand, dass in den spāteren dichtungen Spenser's sich keine blankverse, wol aber vor allem gereimte fünffussige jamben finden, sowie die um- 
schreibung unsres denkmals in späterer zeit in reime, mag mit der vereinsamten stellung des dichters in seinem Irischen exile zusammenhăngen.

In den 'Visions of Bellay' sind vier sonette, die in dem 'Theatre for worldings' fehlen. Andrerseits sind in letzterem vier zum schlusse, die bei Spenser fehlen. Metrisch weichen letztere vier gerade nicht von den andern elf $a b$, doch bemerkenswert ist, dass die ersten elf mit gereimten weiblichen versausgängen (thunder : wonder, wie in den 'Visions') schliessen, welche erscheinung sonst nicht vorkommt und vielleicht den schluss als solchen markieren soll. Ich bediene mich der ausgabe von Morris in der Globe edition.

Silbenmessung.

Die endungen sind meist contrahiert. Der unterschied zwischen adjectivischem particip perfecti schwacher verba und verbalisch gebrauchtem scheint hier unleugbar, obwol sich anch fur letztere verwendung vollmessung findet. Adjectivisch gebraucht ist $\mathrm{z}$. b. bedecked ${ }^{\mathrm{v}}$, astonned ${ }^{\mathrm{VII}}$, was doch sonst besser contrahiert ist.

Synicese von $i(e, u)+$ vocal in der regel: auncient ${ }^{N}$, precious $^{\mathrm{1x} .} \mathrm{xv}$, Dodonian ${ }^{\mathrm{v}}$, Italian ${ }^{\mathrm{v}}$, morian ${ }^{\mathrm{xI}}$, orient $\overline{\mathrm{xv}}$ u. a., vollmessungen am versschlusse: Morpheus ${ }^{\mathrm{xI}}$.

Sonstige syncope: conquering ${ }^{\mathrm{VII}}$, glystering ${ }^{\mathrm{IX}}$, wondrous ${ }^{\mathrm{x}}$,

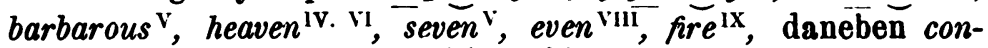
queror ${ }^{v}$, und sehr wirkungsvolle vollmessung vor einer pause in dem verse: I saw new Earlh, new Heaven, sayde Saint John ${ }^{\mathrm{x}}$. Zerdehnung in: Sweetely sliding into th'eyes of men'. Krasis in: seing ${ }^{\mathrm{XI}}$, violent ${ }^{\mathrm{XI}}$. Verschleifung zweier wörter: th'example ${ }^{\mathrm{VI}}$, . th'eyes', th'inconstance ${ }^{\mathrm{X}}$, manyaccordes ${ }^{\mathrm{x}}$.

Wortbetonung.

Einige Romanische betonungen finden sich vielleicht in den versen:

III To beare the frame, four great Lions of golde

VIII Renting hir faire visage and golden haire

$\mathrm{X}$ Clere as Christall against the sunny beames.

Daneben die Englischen betonungen durch den rhythmus gesichert: lion ${ }^{\mathrm{XII}}$, image ${ }^{\mathrm{XII}}$, laurel, sodenly u. a. m.

Von zusammensetzungen zeigt vainenesse ${ }^{\text {II }}$ ein characteristisches beispiel fur die erscheinung, den starken nebenaccent 
in die hebung zu setzen, ohne dass man gerade eine härte verspurt, in dem verse:

II O worldes vainenesse. A sodein enrthquake loe,

wo die etwa spondeisch zu nennende verwendung des wortes schon durch die schreibung veranschaulicht wird. Zur annahme weiblicher caesur nach vorangegangener vollmessung von worldes fehlen die analogiefälle; dazu bietet die umschreibung von 1591: $O^{-}$worlds vainesse!

Der versrhythmus bietet mehrfach trochneen. An erster stelle häufig, z. b.:

II Shaking the hill even from the bottome deepe

XIV Joyning their force to slea the faithful man.

Ausserdem noch neun fälle in I-XI und drei in XII-XV. Rhetorisch ebenfalls nicht selten:

VI Out of hir ashes as a worme arise

XII Feete of a beare, a Lion throte she had.

Innerhalb des verses wirkungsvolle trochaeen. An zweiter stelle nach einer logischen pause:

I So I knowing the worldes unstedfastnesse

An dritter stelle nach der pause:

VI With fecble flight|ventur $c$ to mount to heaven.

An vierter stelle nach der pause:

II All of fine diamant | decking the front

VI I heard the tronke to grone/ und er the wedge.

Härten finden sich hier keine, ausser etwa den bei der wortbetonung angefuhrten fällen.

Ueberzählige silben finden sich nur als weibliche versausgänge, wenn man heaven N. V. VIII. IX. XI. XIII und power XII vollmessen will. Ausserdem noch, und zwar mit sicherheit, in den schon erwälınten schlussversen des XI. sonetts:

And seing hir stricken fall with clap of thunder, With so great noyse $I$ start in sodaine wonder.

In sonett $\mathrm{XII}-\mathrm{XV}$ finden sich keine trochaeen im versinnern. Ein unvollständiger vers findet sich im sonett VIII:

Where all worldes hap was reposed;

er ist in der umschreibung von 1591 mit vermeidung des wortes 'hap' gebessert: In which all worlds felicitie had place, vielleicht ein beweis, dass Spenser ihn für schlecht angesehen, da or auch durch einsetzung von 'happiness' etwa nicht gestimmt hätte. 
Die umschreibung von 1591 zeigt auch die betonung Lyon III, visage ist durch cheekes ersetzt, doch findet sich honour III; fur christall schon christall ${ }^{\mathrm{II}}$. Trochaeen finden sich nur am anfange und einmal an vierter stelle nach der pause: And hundred vanquisht things | under her lay ${ }^{\mathrm{xv}}$. Ich will als probe je ein sonett aus beiden versionen anfuhren. Aus dem "Theatre for worldings':

IX Upon a hill I saw a kindled flame, Mounting like waves with triple point to heaven Which of incense of precious Ceder tree With Balmelike odor did perfume the aire. $A$ bird all while, well fether'd on his winges Hereout did flie up to the throne of Gods, And singing with most plesant melodie She climbed up to heaven in the smoke. Of this faire fire the faire dispersed rayes Threw forth abroade a thousand shining beames, When sodain dropping of a golden shoure Gan quench the glystering flame. O grevous chaunge! That which ersinhile so pleasauut scent did yelde, Of Sulphure now did breathe corrupted smel.

Aus den 'Visions of Bellay':

XI Upon a hill a bright flame I did see Waving aloft wilh triple point to skie, Which, like incense of precious Cedar tree, With balmie odours fild th'ayre farre and nie. $A$ Bird all white, well feathered on each wing, Hereout up to the throne of Gods did flie, And all the vay most pleasant notes did sing, Whilst in the smoake she unto heaven did stie. of this faire fire the scattered rayes forth threw On everie side a thousand shining beames:

$W$ hen sudden dropping of a silver dew (O grievous chance!) gan quench those precious flames; 1 hat it, which earst so pleasant sent did yeld, Of nothing now but noyous sulphure smeld.

Es scheint mir nicht unmöglich, dass die fassung in blankversen nicht die ursprungliche ist; die reimworte smeld : yeld, sing : wing z. b. finden sich in den blankversen wieder. Dazu kommt, dass die blankverse durchaus nicht die charakteristischen eigenschaften des uberspielens der gedanken von verszeile zu verszeile, der satzpunkte im versinnern zeigen. Sie sehen wie erzwungen aus. Sicher freilich ist obige annahme nicht. Die frage sei damit nur angeregt. Jedenfalls 
liegt das interesse an dem besprochenen denkmal nur in.der tatsache seiner existenz. Die form ist weder charakteristisch fur den blankvers der zeit, noch von einfluss auf seine entwicklung gewesen.

Abgeseben von Surrey, war der blankvers ausser im drama also nur vereinzelt aufgetreten; so-ist es vielleicht zu erklären, dass Gascoigne in der oben citierten stelle in seinen 'Notes of - Instruction' nur davor warnt, den sinn eines gedichtes um des reimes willen zu ïndern, und den blankvers selbst nicht erwähnt. Wenige monate nachher (nach dem ersten erscheinen der 'Instructions') aber beginnt er sein Steele Glas, das er im April 1576 vollendet. $\mathrm{Zu}$ gleicher zeit ist er mit seiner Philomene beschäftigt, die er mit dem 'Steele Glas' zusammen 1576 herausgibt. 'The Complaint of Phylomene' ist in der beliebten form der verbindung des alexandriners mit dem siebenfussigen jambus geschrieben und mit gereimten funffussigen jamben ein- und ausgeleitet. Ueber die blankverse seines 'Steele Glas' äussert Gascoigne sich in dem vorangeschickten gedichtchen 'The author to the Reader'. Der dichter sagt darin, dass er ' $a$ fort of fame by science to assault' suche, 'and so to leave remembrance of his name'. Doch meint or:

'The walles thereof are wondrous hard to clyme:

And much to high, for ladders made of ryme.

Then since I see, that rimes can seldome reache Unto the toppe of such a stately Towre,

By reasons force, I meane to make some breache, Which yet may helpe, my feeble fainting powre,

That so at last, my Muse might enter in, And reason rule, that rime could never win.

Such baltring tyre, this pamphlet here beroraies, In rymelesse verse, which thundreth mighty threates, And where it findes, that vice the wal decayes, tiuen there (amaine) with sharpe rebukes it beales. The worke (thinke I) deserues an honest name, If not? I fayle, to win this forte of fame.'

Ich citiere nach der ausgabe in Arber's reprint, worin ich die verse gezählt habe. Es steht v. 1-21 auf s. 49, v. 22-57 auf s. 50, v. 58-93 auf s. 51 , v. $94-128$ auf s. 52, v. $129-160$ auf s. 53 , v. $161-193$ auf s. 54, v. $194-228$ auf s. 55 , v. $229-263$ auf s. 56 , v. $264-297$ auf \&. 57 , v. $298-332$ auf s. 58 , v. $333-368$ auf s. 59 , v. $369--403$ auf s. 60 , v. $404-441$ 
auf s. 61 , v. $442-477$ auf s. 62 , v. $478-512$ auf s. 63 , v. $513-547$ auf s. 64 , v. $548-584$ auf s. 65 , v. $585-619$ auf s. 66, v. $620-652$ auf s. 67 , v. $653-689$ auf s. 68, v. $690-724$ auf s. 69, v. $725-761$ auf s. 70, v. $762-798$ auf s. 71 , v. $799-832$ auf s. 72 , v. $833-864$ auf s. 73, v. $865-900$ auf s. 74, v. $901-937$ auf s. 75 , v. $938-970$ auf s. 76, v. 971-1009 auf s. 77, v. $1010-1047$ auf s. 78 , v. $1048-1084$ auf s. 79, v. $1085-1121$ auf s. 80 , v. $1122-1130$ auf s. 81 .

Silbenmessung.

Die endungen sind meist contrahiert, doch findet sich noch häufig vollmessung: alehouses ${ }^{841}$, princes ${ }^{371}$ neben clothes $^{449}$, youthes ${ }^{243}$, craftes man ${ }^{195}, \overline{l e a r n e d}^{25}$, ravished ${ }^{85}$, marke $\overline{{ }^{92}}$, disgraced $^{236}$, laytere $\bar{d}^{524}$, called ${ }^{69}$, accused ${ }^{926}$, whispere $\overline{d^{50}}$, garnis $\bar{h}$ -

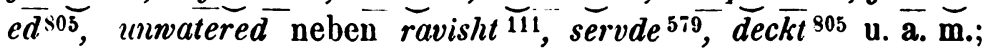
ein unterschied zwischen adjectivischem und verbalem schw. particip ist nicht $\mathrm{zu}$ constatieren; liveth ${ }^{453}$, driveth ${ }^{573}$ neben dotes $^{573}$, condemnes 610 .

Synicese in der regel bei $i(e, u)+$ vocal, vollmessungén jedoch am versschlusse: detraction ${ }^{79}$, companion $u$. a. m. im innern des verses, während $\overline{\mathrm{am}}$ schlusse: foundation ${ }^{213}$, rebellion $^{259}$, religion ${ }^{908}$ u. a. m.; desgleichen courtier ${ }^{755.56}$, souldier 245.472 u. 0̈., valiant ${ }^{550}$, Italian ${ }^{909}$, furious ${ }^{538}$ u. a. m. neben vollmessungen am versschlusse: courtier ${ }^{763}$, souldier ${ }^{465 .}{ }^{560.632}$, ex-

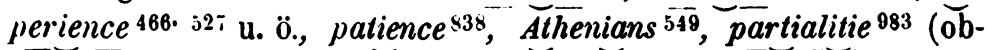
wol hier nicht die letzten zwei silben in betracht kommen).

Synkopierungen sind sehr häufig: heaven ${ }^{356 \cdot 400}$, even ${ }^{\mathbf{3 2} \cdot 186}$, cvery $^{25.4} 411$ u. o., power ${ }^{280}$, murdring ${ }^{9}$, slaunderous ${ }^{46}$, broydrie ${ }^{777}$, savry ${ }^{779}$, savrinesse $\overline{831}$ neben vollmessungen wio ever ${ }^{475}$.

Verschleifungen zweier worter: you one ${ }^{675}$, sistr' and $1^{59}$.

Wortbetonung.

Gascoigne hat seine regeln uber richtige Englische betonung so ziemlich gehalten. Ein einziges mal betont er mischiefe $^{392}$, und zwar durch den versschluss verburgt, gegenuber sonstigem mischief 200.1037 . Seine andern unregelmåssigkeiten beruhen sämtlich auf zu weit gegangenem zurtekziehen des tones. Er bietet dreimal maintain:

299 To maintaine pompe and high triumphant sights

889 To maintaine truth and therwith stil to wey

978 With curious Quids, to maintain argument, 
wie in der 'Jocasta' sich einmal ordein findet (vgl. Chaucer, Kn. T. 583, desgl. Minot bei Mätzner, Sprachpr. I 322, 36, Abbott, Sh. Gr. 394), ferner einmal purveyour ${ }^{1098}$ (vgl. Abbott s. 396): When purveyours provide not for themselves ${ }^{1095}$ neben surveyour ${ }^{1106}$, und einmal findet sich sogar between im verse: But beare the bridle, evenly between both ${ }^{928}$ höchst auffallend im verse verwendet. Ich muss da gleich vorgreifen und bemerken, dass im 'Steele Glas' keinerlei härten, kein trochaeus im versinnern sich findet. Die ofterwähnten wörter into, unto wären die einzigen fälle in den versen 59, 78, $340,533,888,914,1076$. Da Gascoigne so sorgsam auf strengen rbythmus gesehen, können wir wol nicht umbin, anstatt ihm bärten aufzudrängen, die strittigen fälle auf schwankende betonung zurtickzufuhren, schwankend wol weniger in prosaischer rede, sondern, wie schon oben bemerkt, nur insofern, als ihre verschiedene verwendung im verse nicht als härte empfunden wurde. Auch in between mag die zweiteiligkeit noch in sprachbewustsein gelegen sein. Dass wir in gelehrten ausdrïcken die betonungen: philosophy ${ }^{974}$, cosmography ${ }^{980}$, astrology ${ }^{1000}$ neben rhetorick ${ }^{994}$, sophistry ${ }^{979}$ u. a. m. finden, wird uns nicht wunder nehmen. Ebensowenig am versschlusse cento pro cento.

Der versrhythmus ist im 'Steele Glas' also ein höchst regelmässiger, ja zu regelmässiger, um nicht monoton zu sein. In der caesur ist wenig abwechselung, sie fällt meist nach der vierten silbe.

Trochaeen finden sich nur an erster stelle, und zwar sehr selten, z. b. Only that king proud Tereus by his name ${ }^{9}$, ausserdem noch v. $73,715,883$ (722).

Ueberzählige silben finden sich im versinnern, ausser den zusammensetzungen nur in dem verse: The knight a Lord, the Lord an Erle or a duke ${ }^{406 .}$

Weiblicher versausgang findet sich einige male:

ist To teach young men the trade to sel browne paper

864 Without regard of outward ceremonies

\$94 Tell some in Spain how close the kepe their closets

1107 When silver sticks not on the Tellers fingers.

Vielleicht auch:

573 And so becoms example of much evil und

949 Do neither care, for God nor yet for devill, 
wo freilich die beiden auslautenden wörter einsilbig gelesen werden könnten.

Weibliche caesur findet sich gar nicht.

Kürzere oder längere verse liess der dichter sich nicht zu scliulden kommen.

Reime finden sich wenige mituntergelaufen: wel:dwel ${ }^{59 \cdot 90}$, despise : wise ${ }^{3850} 386$.

Alliteration ist nicht selten:

is7-is9 To binde such babes, in father Derbies bands

To stay their steps, by statute Staples staffe

To rule yong roysters, with Recognisance

259 No right revenge, doth rayse rebellion u. a. $\mathbf{m}$.

Wie wenig auch hier von den vorzügen des blankverses yebrauch gemacht ist, zeigt eine probe:

v. 1061 But here me thinks, my priests begin to frowne, And say, that thus they shal be ouerchargde, To pray for al, which seme to do amisse: And one I heare, more saucie than the rest, Which asketh me, when shal our prayers end? I tel thee (priest) when shoomakers make shoes, That are wel sowed, with neuer a stich amisse u. s.w.

Der wackere Gascoigne hätte fruher auf den gedanken verfallen sollen, sich in nichtdramatischen gedichten des blankverses zu bedienen. So ist es ihm leider nicht gelungen, ein 'battring tyre' $\mathrm{zu}$ entwickeln! Nichtsdestoweniger ist Gascoigne's werk gewis von bedeutendem einfluss gewesen, gerade durch die glătte, die es charakterisiert.

Zunächst gibt nun Percy für das jahr 1584 'Precepts for a State' by Barnaby Rich an, worunter wol ein gedicht in 'The second Tome of the travailes and adventures of Don Simonides' etc. by Barnabe Rich, London 1584, gemeint ist. Collier verdanken wir eine kleine probe, die uns aber wenig bietet. Silbenmessung, wortbetonung (ausser etwa dem verse: To fashion raines unto your wondering willes), versrhythmus zeigen nichts erwähnenswertes. Keine trochaeen, keine weiblichen ausgänge und caesuren, keine grösseren ruhepunkte innerbalb des verses. Collier bemerkt dazu auch:

'There are about one hundred and seventy lines in this poem, but none of them have that variely of pause and inflection which Marlowe earliest employed upon the Stage in his 'Tamburlain the Great', and which Shakespeare subsequently so much improved'. 
John Lyly's 'The woman in the moone' ist fur die geschichte des vor-Marlowe'schen blankverses von yrossem interesse, wenn es, wie wol anzunehmen, 1584 zur auffuhrung kam. Da Lyly's tubrige stucke - uber The Maid's Metamorphosis vgl. Ward Hist. of E. Dr. L. I 169 - in prosa geschrieben sind, ist es erklärlich, dass diese auch in seinem blankrers. drama gelegentlich vorkommt, doch, wie wir sehen werden, nicht planlos.

Ich citiere nach der seitenzahl in Fairholt's ausgabe von Lyly's Dramat. works, London 1858.

Die silbenmessung bietet nichts auffallendes. Vollmessungen finden sich bei ableitungssilben mit $i$ + vocal gerade so im versinnern wie am versschlusse. Stesins ${ }^{180}$, Stesias ${ }^{191}$ im innern, Stesias ${ }^{190.191}$, Stesias ${ }^{198}$ am schlusse u. a. m. Verschleifung zweier w.örter: further our ${ }^{166}$, follow her ${ }^{210}$, lay aside ${ }^{197}$, me afeard ${ }^{197}$, he is ${ }^{179}$ u. a. $\bar{m}$. Krasis: being ${ }^{189}$, seeing ${ }^{209}$, zerdehnung: wondrous ${ }^{15}$.

Die wortbetonung bietet einige fälle Romanischer tuberreste in den versen:

151 The heavens themselves envy her glorious worke

176 For though at first Phoebus envied her looks, welche fälle nicht nötig so gefasst zu werden hrauchen, da die betreffenden worte wirkungsvolle trochaeen geben kinnten, doch

178 Ah, I envie her, why was not I so,

200 In spite of nature that envies us all

199 She is honest, but thou wouldst seduce her

191) This words argue Pandora to be light gegenuber argue ${ }^{195}$. Ferner aspect (subst.) am versschlusse in der schlussrede des 5 . acts.

$\mathrm{Zu}$ weit gurlickgezogenen ton zeigen das obige seduce, sowie disperse im verse: $O$ thus be my love disperst into the ayre ${ }^{205}$. In letzterem falle werden wir wol besser zweisilbige senkung be my annehmen. unto, into ubergehe ich hier und im folgenden ganz. Betontes end-e wird in dem verse: Thinking to take us together here ${ }^{185}$ wol anzunehmen sein, vielleicht auch in Milk-white squirrels, singing popinjayes 209, wo aber besser fehlender auftact anzusetzen wäre.

Der versrhythmus bietet weit mebr beachtenswertes.

Zunächst eingestreute trochaeen wie in andern denkmälern. Am versbeginne häufig: 
- 179 Happy are those, that be Pandora's guests, desgleichen auf s. 153,154, 156, 159, 167, 173, 176, 177, 178, 180, 182, 183, 202, 205, 206, 207 (4 mal), 209.

An dritter stelle nach der pause:

154 Pleasand and sad, $\mid$ mooving and fixed things, desgleichen auf s. $160,165,166,170$ (2 mal), 174, 195, 197, 203, 206.

An vierter stelle nach der pause:

180 May move thee unto rueth, | pity my state

171 So shall she now become, I gentle and kinde.

Im gegensatze zu diesen recht zahlreichen, fällen wirkungsvoller trochaeen finden sich wenige härten, die durcb nichts zu rechtfertigen sind:

186 My heart ryseth against this Iphicles,

166 Whether now, my maisters, in such post hast

206) And tell the bell-wether I heare him not.

Ueberzählige silben im versinnern sind nicht selten, z. b.:

178 Mistresse, here be the hearbs for my masters wound u. a. m. Weiblicher versausgang vereinzelt im verse:

203 And singing popinjayes? a boat of dear-skins?

Weibliche caesur auch selten nach der vierten silbe:

176 Wanton discourses, musicke and merrie songes

198 When I forsake thee, then heaven itselfe shal fall

nach der sechsten silbe:

200 We are almost at the seaside, I pray thee ryse.

Nicht aus den augen zu lassen ist die erscheinung, dass wir hier zumeist einzelne wörter, nicht nur endungen in der uberzäbligen silbe haben.

Einmischung kurzerer, langerer und tberhaupt anderer verse und prosa.

Zahlreiche falle finden sich, wo nur einige versfusse für einen blankver's stehen, wie in der 'Jocasta'; einerseits mitten in der rede einer person:

Yet must 1 make as if I love them both;

Here they come (eigentlich nur $1 \frac{1}{2}$ tact)

186 Wel come Learchiss to Pandora's feast,

andrerseits zum schlusse einer rede, wie z. b.:

And singing popinjayes? a boat of dearskins?

203 Come I'le goe! I'le goe! (exeunt odor 
Pand. I had not chosen Stesias for my love But now -

Learch. Lovcly Pandora, if a shepherds teares (180).

Auch zu beginn einer rede, ohne fortsetzung eines vorbergehenden verkurzten verses zu sein:

1, but he shall not.

1s4 His fellowswaines will méete me in this bower.

Am häufigsten aber alleinstehend, als eingeworfene bemerkung, wie z. b.:

Learch. I like not that she whispers unto him.

Iphicl. I warrant you.

Pand. Her's to the health of Stesias my love (186), ebenso s. 186, 190, 210 u. ö.

Oftmals ist nicht zu unterscheidęn, ob das eingestreute prosa sein soll oder ein versfragment.

Scheinbar schlechte verse:

188 And I beat thee for good will to her und Theevish, lying, suttle, eloquent

sind durch sogenannten fehlenden auftact zu erklären.

Von eingestreuten längeren versen sind als aus zufall hereingekommene 6 füssige jamben die verse anzusehen:

172 And thou Gunophilus, I pray thee pardon mee

189 She singing on her lute and Melos being the note.

Doch in die rerse auf \&. 202:

- but I will sing:

Stesias hath a while hand, but his nayles are blacke,

His fingers are long and small, shall I make them cracke?

One, two and three, I love him, and he loves me.

wird man kaum einen regelrechten rhythmus hineinbringen können. Es sind doggerel-rhymes, oder wie Abbott sagt 'comic trimeters'.

Es folgen darauf vier 3 tactige verszeilen, reimend $\mathrm{a} b \mathrm{~b}$ a:

Beware of the shephooke;

I'le tell you one thing,

If you aske me why I sing

I say yee may go looke.

Ebenso sind s. $17 \bar{t}$ in der scene zwischen Pandora und Joculus gereimte kthrzere verse:

Joculus. Were I a man I could love thee

Pandora. I am a mayden, wilt thou have me?

Joc. But Stesias saith you are not.

Pand. What then? I care not. 
C'upid. Nor I. Joc. Nor I.

pand. . Then merely farewell my maydenhead,

These be all the teares I'le shed;

Turne about and tryppe it.

Ebenso wie die prosa des Gunophilus in der mir vorliegenden ausgabe oftmals in der art von versen abgedruckt ist, so dass man sich oft lange vergebens bemuht, dieselben zu scandieren, erscheinen einige verspaare unrhythmisch durch unrichtige versabteilung:

Not, not, not, that you should not come unto $\mid$ me

206 This night not at all, at all, at all.

But Cynthia made me idle, mutable, | forget ful

210 Foolish, fickle, franticke, madde;

wahrscbeinlich auch in den versen:

Bring Sphicles and Mclos with thee and tell $\mid$ them

181 Of my husband, descendit ad inferos.

Lateinische veíse sind mehrfach eingemischt. Ausser dem fall im letztangefuhrten verse finden sich Lat. distichen auf s. 175, 176, ein pentameter 175, wo diese verse je eine zeile für sich in anspruch nehmen, ferner eingestreute Lat. sätze, die nicht immer als verse zu erkennen sind. Dem versihythmus des Englischen sind sie aucb nicht immer angepasst.

In der verwendung der prosa unter blankversen ist eine ganz deutliche absicht zu erkennen, indem nämlich der clown des stuckes, Gunophilus, sich derselben in der regel bedient, nur ganz vereinzelt in blankversen spricht. Es ist da ebenfalls häufig Gunophilus' prosa in versform gedruckt, so dass man hieruber leicht getăuscht wird. Nicht nur in golegentlichen monologen, sondern mitten unter lebendigster conversation platzt Gunophilus prosa in die blankverse hinein, z. b. s. 179:

Pand. I'le hide thee in a wood, and keepe thee close.

Gunoph. But what if he come ahunting that way?

Pand. l'le say thou art a Satyre of the woods.

Gunoph. Then I must have hornes.

Pand. I, so thou shalt, I'le give thee Stesias' hornes u.s.w.

Dabei aber herscht ungleichmåssigkeit insofern, als Gunophilus gelegentlich auch in verse verfällt, gleich darauf aber wieder in prosa antwortet, wie z. b. auf s. 161:

Gunoph. She is not tongue-tyde, that I know by proofe.

Melos. Speake once, Pandora, to thy loving friends. 
Pand. Rude knaves, what means you thus to trouble me?

li un oph. She spake to you, my maisters, I am none of your company.

Darauf nach blankversen von Learchus wieder zwei von Guuophilus. Dies ist aber als unachtsamkeit gegenüber dem wolbeabsichtigten plane anzusehen. Andere personen geraten nur zuweilen in prosa, und zwar nur in kurzen ausrufen, fragen u. dgl., die man aber als verkürte verse auffassen kann, wovon schon oben die rede war, z. b.:

Iphicles. Let him goe, darauf ein blankvers

Melos. Pandora, go with me to Stesias.

und wieder

Iphicles. No rather goe with me.

Melos. Away, base Iphicles.

hierauf wieder blankverse. Ausserdem in kleinen zwischenreden mit Gunophilus, so s. 201, 204.

Reim findet sich, wie in der 'Jocasta', wirkungsvoll angewandt, um einen grössern abschluss zu markieren; so am schlusse des 2. acts:

And thus I leave her, all incenst with yre,

Let Sol coole that which 1 have set on fire.

Ebenso gleiche reime am schluss der 1. scene des 3 acts:

Even now beginneth my furie to retyre

And now with Stesias hence wil I retyre.

Möglicherweise auch zum schluss des 3.' acts:

Stesius. And I beat thee for good will to her.

What hast thou to doe betwixt man and wife?

Gunoph. Too much with the man, too litle with the wife.

wenn wir hier nicht prosa annehmen mussen, da der erste vers zwar noch durch fehlenden auftakt erklärlich, der zweite aber doch gar lart klingt, besonders durch das belwixt (vgl. das between bei Gascoigne im 'Steele Glas').

Alliteration zeigt sich gelegentlich, z. b.:

169 I, so fayre and far off, for feare of hurt

See how the cowards counterfel a fray

175 Come my Pandora, Slesias stayes for thee $\mathbf{u} . \mathrm{a} . \mathrm{m}$.

Die verteilung eines verses auf mehrere redner ist nicht selten z. b.:

Iphicl. .. Helpe Iphicles. Melos. Melos must speed or dye (166). 
Melos. But ere I slept - Learch. When 1 had list - Iphicl. What then? (189)

so noch ziemlich hăufig. Immer ist aber nur ein vers so geteilt, zuweilen möchte man mehrere vermuten, doch sind diese vermeintlichen bruchstlucke meist abgerissene, prosaische sătze.

Enjambement ist selten, wie uberhaupt der rhythmus gerade nicht sehr gelungen zu nennen ist. Die einmischung der abgerissenen sătze, die allzuhăufig vorkommt, gibt dem ganzen einen etwas unbeholfenen anstrich. Zur probe diene die schlussrede von Nature, am ende des 5. acts:

Now rule, Pandora, in fayre Cynthia's steede, And make the moone inconstant like thyselfe;

Raigne thou at women's nuptials, and their birth;

Let them be mutable in all their loves,

Fantasticall, childish and foolish, in their desires,

Demaunding toyes: and starke madde

When they cannot have their will.

Now follow me, ye wandr'ing lightes of heaven,

And greive not that she is not plast with you;

All you shall glaunce at her in your aspects,

And in conjunction dwell with her a space.

Die probe zeigt gleich die holprigkeit des versihythmus. Vermutlich ist zu scandieren:
Fantasticall, childish and
Foolish in their desires, demaunding toyes:
And starke madde when they cannot have their will,

d. $b$. in der erstgeschriebenen zeile vernachlässigt der dichter sein versschema, und ist zufrieden, wenn von foolish an die scansion wieder in schwung kommt.

Hat nun in formeller hinsicht auf die reinigang der poesie dies werk Lyly's keinen günstigen einfluss uben können, so ist es doch nach zwei seiten hin von interesse: einerseits fur die beurteilung des dichters, dass er, der auf die entwicklung der poetischen prosa von so grossem einfluss gowesen war, sich auch der strōmung, die gegen den reim ankămpfte, angeschlossen; andrerseits dadurch, dass or zuerst in einem blankversdrama prosa anwendete, und $z$ warim gegensatze zu den gehobenen blankversen, fur die rolle des clown, und in gloicher weise den knittelvers der volkstumlichen comödie zu scherzhaften effecten einmischte. 
Die in Peele's werken sich findenden blankversdichtungen vor dem jahre 1587/8 sind:

1. Lines addresed to Thomas Watson, 1582;

2. Einige reden in dem festspiel 'The Arraignment of Paris' 1584;

3. Der prolog zu dem Device of the Pageant borne before Wolstan Dixi, 1585.

Ich citiere nach der.seitenzahl von 'The dramatic and poetical works of Robert Greene and George Peele', hrsg. von Dyce, London $187 \dot{4}$.

1. bietet nichts bemerkenswertes in den 11 zeilen, ausser einem weiblichen verausgang: melancholy.

2. Die blankverse in 'The Arraignment of Paris' sind insofern interessant, als sie uns zeigen, wie man sich des unterschiedes zwischen gereimten und reimlosen füffussigem jambus immer mehr bewust wurde. Die wichtigsten, nachdruckvollsten stellen sind in blankversen geschrieben, wăhrend die anderen scenen und dialoge, die meist in gereimten funffüsslern abgefasst sind, den rhetorischen prachtsticken nur zum rahmen dienen. In blankversen sind abgefasst: der pro$\log$ s. $351 \mathrm{a}, \mathrm{b}$, Oenone's complaint s. $360 \mathrm{~b}$, Paris' oration to the Council of the Gods s. $365 \mathrm{a}, \mathrm{b}, 366 \mathrm{a}, \mathrm{b}$ (unterbrochen einmal von einer verszeile eines gegenredners, und einmal von einem reimpar), Diana describes the Nymph Eliza $368 b$, $369 a$, Clotho speaks to the Queen $369 a$, 370 a.

Die silbenmessung zeigt kräftige contractionen: conquering ${ }^{351 ",}$ flowers 369. , reverence 370 " u. a. m., daneben vollmessungen am versende: partiality ${ }^{305}$ "; auch in den participien auf - $e d$, ohne unterschied in verbalem oder adjectivischem gebrauch, destined ${ }^{366 \text { ", }}$ ycleped $^{369}$ a a. a. m. Verschleifung zweier wörter: th'unhappy ${ }^{351}$, t'appease ${ }^{351}$ u. a. m. Zu bemerken to parle ${ }^{365}$ vor consonanz.

Die wortbetonung zeigt wenig bemerkenswertes: möglicherweise contrary im verse: $A$ favour, for indeed, con"rary kind "370" und im verse: The question standing upon beauty's bluze $^{360 "}$ in upon wieder ein zwangloser gebrauch der zweiteiligkeit einer praeposition, wie sonst hăufig bei unto, into.

Der versrhythmus zeigt gelegentlich trochaeen recht wirkungsvoll. 
An erster stelle: Under the climate of the milder heaven ${ }^{369 a}$, ebenso gracious ${ }^{369} \mathrm{~b}$, noble $^{370 \mathrm{n}}$.

An dritter stelle: And so preferr'd beauty before them all 366a, dass hier nicht beauty zu lesen, beweisen die auf derselben seite stehenden zahlreichen betonungen beauty.

An vierter stelle: Whose thick and foggy smoke, piercing the sky ${ }^{35 t a}$ und Perform in Ida vales. Lordings adieu ${ }^{351 " .}$

Härten sind mir nicht begegnet.

Ueberzählige silben im versinnern: Surcharg'd with the burden that she will sustain 351 u. a.m.

Weiblicher versausgang findet sich nur zweimal: presence $^{365 \mathrm{~h}}$, excellency ${ }^{370 \mathrm{l}}$. Weibliche caesur gar nicht.

Das interessanteste aber sind die reime und zwar am schlusse der rede $366 \mathrm{~b}$ : be : me, $369 \mathrm{a}$ : wrong : belong, $370 \mathrm{~b}$ : worthiness : godessess, die sehr wirkungsvoll sind. Ohne reim am schlusse blieb der prolog, sowie Oenone's complaint, welch letzteres stück als gesang in drei vierzeilige strophon geteilt ist.

Eine probe aus Paris' oration:

My dazzled eye did swerve or surfeit more

On Venus' face than any face of theirs,

It was no partial fault, but fault of his;

Belike, whose eyesight not so perfect was

As might discern the brightness of the rest.

And if it were permitled unto men,

Ye gods, to parle with your secret thoughts,

There ben that sit upon that sacred seat,

That would with Paris err in Venus' praise.

Wir sehen sehr schön fliessenden rhythmus, doch keine benutzung der freiheiten des blankverses. Auch die gereimten funffussler zeigen eine gewisse formvollendung. Das interesse, das die blankverse in 'The Arraignment of Paris' bieten, liegt also lediglich in der art ihrer verwendung unter gereimten versen.

3. Der prolog vor 'Pageant before Walton dixi' ist ziemlich glatt gebaut. Wenig ist $\mathrm{zu}$ bemerken. England stelt einmal im letzten fusse, darauf ein reim: hand, vielleicht beabsichtigt. Trochaeen finden sich nur vier an erster stelle: Beauti fied und Service, science, seated. Der schluss des ganzen ist ungereimt. Hier zeigt sich der blankvers schon besser benutzt, 
der rhythmus ist kräftig und ktinstlerisch getragen. Eine probc mag hier stehen:

And London, by these friends so happy made,
First thanks her God, the author of her peace,
And next with humble gesture, as becomes,
In meek and bowly manner doth she yield
Herself, her wealth, with heart and willingness,
Unto the person of her gracious queen,
Elizabeth renowned through the world,
Stall d and anointed by the highest power,
The God of kings, that with his holy hand
Hath long defended her and her England $\mathrm{u.s.}$.

Das kleine gedicht Robert Greene's 'The description of Silvestro's Lady', aus seinem 'Morando, the Tritameron of Love', 1587 bei Dyce 8. $285 a$, ist ebenfalls glatt und regelrecht gebaut. Es findet sich nur ein zu langer vers:

\section{.... those two moving hills}

Which, topp'd with pretty teats, discover down a vale,

den der herausgeber für einen alexandriner oder einen corrupten vers ansieht. Ich glaube an corruption ist es nicht nötig zu denken. Dass verse durch zufall um einen fuss lănger oder kurzer geraten sind, baben wir schon oft bemerkt. Zudem mag pretty nachträglich als unentbebrlich eingeschaltet worden sein, da die stelle ohne dasselbe zu schmucklos erschienen. Die zwei andern gedichte im 'Morando' sind in gereimten funffusslern, wie uberhaupt sehr viele von Greene's gedichten. Es zeigt uns dies denkmal wieder nur, wie vereinzelt und vorsichtig man mit der anwendung des blankverses in undramatischen dichtungen experimentierte.

'The misfortunes of Arthur' wurden zu Greenwich vor der königin am 8. Februar 1587/8 aufgefuhrt. Das stluck ist im ganzen von Thomas Hughes verfasst, eine Introduction schrieb Nicholas Trotte, zwei chöre (zum 1. und 2. act) verfasste Francis Flower, und zwar in gereimten funffusslern, während sonst die chöre auch in blankversen abgefasst sind. Für die monologe von Gorlois zu anfang und zu ende des sttucks hat William Fulbecke zwei andre verfasst, die bei der auffuhrung statt der von Hughes genommen wurden; sie sind auch in blankversen. Die mitwirkung von Yelverton, Bacnn, 
Lancaster und Penruddock betraf nur die darstellung, nicht den text des dramas.

Ich citiere nach der seitenzahl in der ausgabe von Hazlitt in Dodsley's collection 1874, 4. bd. Trotte's Introduction steht daselbst s. 255-259, das drama s. 263--339, Fulbecke's monologe s. $340-343$.

\section{Silbenmessung.}

Die endungen sind bei allen dichtern meist contrahiert, doch finden sich noch häufig vollmessungen.

pleas'd $^{258}$, admir'd ${ }^{258}$, enjoin'd ${ }^{259}$, achieved ${ }^{255}$, decreed ${ }^{269 \cdot}$ 29.2, despoild ${ }^{263}$, poisoned ${ }^{263}$, enjoyd ${ }^{278}$, extolld ${ }^{206}$ neben acouched ${ }^{255}$, argued ${ }^{256}$, deemed ${ }^{271}$, engaged ${ }^{267}$, cursed ${ }^{265}$, sufficed ${ }^{266}$.

loathes 264 neben maketh ${ }^{275}$, breatheth ${ }^{266}$, schooleth ${ }^{256}$ u. a., fewer ${ }^{376}$, safest ${ }^{275}$, sagest $^{292}$, greatest ${ }^{316}$.

Synicese findet nicht statt: gracious ${ }^{255}$, various ${ }^{256}$, furious ${ }^{270}$, impious $^{274}$, religion ${ }^{265}$, perfection ${ }^{25 \overline{7} \cdot 259}$, specially ${ }^{256}$, imperial ${ }^{25}{ }^{25} \cdot 265$,

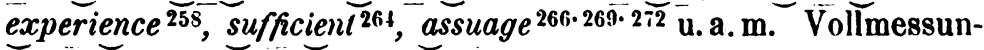
gen derart kaum.

Syncope eines $e$ oder gleichwertigen vocals ist ebenfalls sehr häufig, und zwar stärker als sonst: conquerors ${ }^{288 \cdot 289 \cdot 309}$, vent'red ${ }^{322}$, n'eer ${ }^{259 \cdot} \cdot 273$ u. ö., sovereign ${ }^{258 \cdot 276}$, traitorous ${ }^{261 \cdot 278}$, history ${ }^{257}$, watery ${ }^{259}$, timorous ${ }^{283}$, desperate ${ }^{26 i .} 2 \overline{72}$ u. $\widetilde{0}$., fire ${ }^{270}$. ${ }^{276}$ u. o. ${ }^{2}$ every ${ }^{272}$, ever ${ }^{317}$ neben ever ${ }^{270}$, countenance ${ }^{316}$, dest'ny 203. 294, ofiner ${ }^{208 .} 317$ u. a. m.; dasselbe mit einer art krasis: prayer ${ }^{284}$, to low'r 301.

Verschleifungen zweier wörter ebenfalls sehr beliebt: t'assuage $^{265}$, $t^{\prime}$ enrich ${ }^{259}, t^{2}$ employ ${ }^{258}$, be it ${ }^{259 \cdot 338}$, he'nnoys (annoys) ${ }^{324}$, th'unhappiest ${ }^{336}$, t'one, t'other ${ }^{338}$. Apocopen eines vocals: lasting 'clipse ${ }^{324}$, 'iwould ${ }^{334}$, 't was ${ }^{282}$, con 'suage ${ }^{322}$ u. o., desgleichen t'have ${ }^{315}, b$ 'advised 282 .

Es ist in diesem denkmal also jedenfalls eine grössere freiheit in der silbenmessung zu bemerken, als bei den vorhergehenden.

Die wortbetonung bietet nur einige Romanische betonungen in den versen:

257 Revolve records of deep judicial acts

265 And mild aspect all prone to Britain's good

282 Well, 't was my first conflict: I knew not yet, 
ausserdem das heute noch schwankende puissant : puissant, 293. 294.

$\mathrm{Zu}$ weit zurückgezogenen ton zeigt das adjectiv expert in dem verse:

288 Mark then the odds: he expert, you untried.

Möglicherweise ist in dem verse:

288 He that envies the valour of his foe,

envies Romanisch betout, dass sich bei Fulbecke als envied sogar in reime auf untried findet s. 297; doch charakteristisch ist es fur diesen und derartige fälle, dass auf derselben seite 288 sich einmal envie durch den rhythmus gesichert und ein anderes mal envie an erster stelle findet, wo wir beides annehmen können. Es ist überhaupt auch bei Romanischen wörtern zwischen compositionen und ableitungen zu unterscheiden; erstere können, sobald ihre zweiteiligkeit noch im sprachbewustsein lebt, viel leichter schwankend betont werden.

Germanische composita bieten nichts auffalliges in der betonung; nur einmal findet sich bei Fulbecke ein vers wie:

743 Whose presence makes the earth fruitful to thee, ebendaselbst foresight und einmal bei 'Trotte upon an der stelle eines trochaeus, in dem unten angefuhrten verse 256.

Die eigennamen, sie sind hier keine Lateinischen, sind im ganzen gleichmässig betont, Pendragon, Arthur, Gueneverc, Mordred.

Der versrbythmus zeigt die merkwurdigkeit, dass bei der grossen kuhnheit des versbaues, die sich in den contractionen zeigt, sowie bei der freizligigkeit binsichtlich der pause, trocliaeen möglichst vermieden erscheinen. Am meisten finden sich noch an erster stelle; bei 'T'rotte:

256 Clamours of courts and cavils up on words bei Hughes:

266 Anger delays, my grief gins to assuage, ebenso Hatred ${ }^{267}$, nature ${ }^{268}$, either ${ }^{310}$, nearer ${ }^{312}$, murlher ${ }^{337}$, treason ${ }^{337}$. Bei Flower:

276 Guarded with fear, supported with debate.

Ausserdem rhetorische trochaeen:

255 Hear and discern how just our quarrel was Trust t'it, their faith will faint, where fortune fails. 
Sonst findet sich nur bei Hughes ein trochaeus an vierter stelle:

C. The subjects' force is great. M. Greater the kings.

und bei Fulbecke je einer an dritter und vierter stelle nach der pause:

341 Let blood contend with blood | father with son

Ye ravening birds $\mid$ vnder Celaeno's power.

Mehr zu bemerken ist über die einmischung überzähliger silben, die mit den contractionen im zusammenhange steht, z.b.:

265 And whosoever besides, ye heavenly powers

334 Then mought I've liv'd t'enlarge the Brilon's praise

829 And boist'rous throngs of warriors threatning blood n.a.m.

Dass dergleichen verse den rhythmus sehr beleben, ist natürlich, zumal da sie nicht aus ungeschick so geraten sind.

Weiblicher versausgang findet sich nicht, ausser dem falle:

He will forgive that needs must be forgiven,

wo forgiven leicht contrahierbar ist.

Weibliche caesur findet sich nur einmal bei Trotte:

258 Such as of subjects | allegiance doth require und möglicherweise einmal bei Hughes in dem verse:

264 Let Guenevera| express what frantic moods, wo aber wol verschleifung von Guenevra express stattfinden kann.

Kürzere und längere verse sind gelegentlich unter die blankverse gekommen.

Ein achtsilbler:

273 That nothing olse were to be fear'd, mehrere zwölfsilbler:

168 Each fault requires an equal hate: be not severe

288 'Tis his insatiate mind, that is not so content

295 An'd bears my body back. 1 inwards feel my fall and

316 And as for Mordred's desperate and disloyal plots.

Reime sind nicht zu bemerken, ausser zum schluss des zweiten monologs von Fulbecke, wo wol mit absicht sich folgende finden:

Whose face deters the hags of hell from thee,

Whose virtues hold the plagues of heaven from thee,

Whose presence makes the earth fruilful to thee,

And with foresight of her thrice happy days,

313 Britain, I lectve thee to an endless praise. 
Eine ganz andere rolle spielt aber die alliteration, und zwar bei allen an den 'Misfortunes' beteiligten dichtern, wenn auch nicht uberall so in die augen fallend wie bei Hughes.

Es finden sich einerseits verse mit nur ei nem reim, wie z. b.:
257 And lose their wits all in unwonted walks
313 Fresh rising tempest tires the tossed minds
314 And stir and strive and storm and all is vain
334 That free from force of foreign foes, there rests
278 Pendragon broild with flames of filthy fires
340 Myself by precept of Proserpina.

(es ist wol nicht nötig, zu bemerken, dass tuber die qualität des stabreims keine sichere regel zu abstrahieren ist, da ja nirgends bewiesen werden kann, ob an einer betr. stelle reim anzunehmen ist oder nicht, da dieser ja nur schmuck ist).

Andrerseits finden wir aber auch doppelreime und zwar wie in der Mengl. langzeile gekreuzt und parallel gereimt (vgl. Rosenthal, Die allit. langzeile, Anglia I 437), in welch letzterem falle die beiden versteile zuweilen in beabsichtigten gegensatz zu einander gestellt werden. Z. b.:

313 Who strives to stand in pomp of princely port

296 Seek not the fair that soon will turn to foul

- 341 Wearied with wounds thou didst descend to us

335 The checrless change, the easeless brunts and broils

2:8 How foul his foul, how bitter his rebuke u. a.m.

Die alliteration, die in der Mengl. langzeile schon ihre aufgabe als verbindendes element fast gănzlich verloren und als blosser schmuck betrachtet wurde, wird bier auch nur als solcher anzusehen sein. Gascoigne's äusserung daruber ward schon besprochen.

Ueber die quellen der 'Misfortunes of Arthur' scheinen keine untersuchungen angestellt worden zu sein; ob sich aus denselben vielleicht eine motivierung der hier so auffallend häufigen alliteration finden liesse? Auch uber Hughes selbst scheint nichts näheres bekannt zu sein.

Die verteilung eines verses auf mehrere redner ist bis zum ubermass angewendet, so dass man oft muhe hat, den vers herauszufinden. Eine probe will ich hierher setzen, doch die einzelnen verse durch eine neue zeile kenntlich machen. 
S. 303/4:

Howell. If fortune fawn. Arth. Each way on me she frowns;

For win 1, lose 1, both procure my grief.

Cador. Put case you win, what grief? Arth. Admit I do,

What joy? Cad. Then may you rule. Arth. When 1 may dic.

Cad. To rule is much. Arth. Small if we covet nought.

Cad. Who covets not a crown? Arth. He that discerns

the sword aloft. Cad. That hangeth fast. Arth. But by

a hair. Cad. Right holds it up. Arth. Wrong pulls it down.

C'ad. The commons help the king. Arth. They sometimes hurt.

Cad. At least the Peers. Arth. Seld, if allegiance want.

Cad. Yet sovereignty. Arth. Not if subjection fail.

Cad. Doubt not: the realm is yours. Arth.'T was mime till now.

C'ad. And shall be still. Arth. If Mordred list. Cad. 'Twere well your crown were won. Arth. Perhaps 'tis better lost.

H. The name of rule should move a princely mind.

Ebenso, wenn auch nicht in so langer aufeinanderfolge von rede und gegenrede auf s. 268, 275, 276, 277, 283, 284, 286 u. ö. Diese lebhaftigkeit des dialogs fanden wir, doch nicht in dem masse, im 'Gorboduc' und 'Jocasta'. In 'The Woman in the Moon' fehlte die rhythmische einheit.

Das enjambement ist häufig sehr kühn, z. b. s. 293:

Besides as much in Kent as Horsa and

Hengistus had -

oder s. 295:

My thoughts misgive me much. Down terror! I

Perceive mine end -

Eine probe wird dies, die satzpunkte im versinnern, wie den wechsel der pause, veranschaulichen.

Aus der 4. scene des 1. acts:

Weak is the sceptre's hold, that seeks but right.

The care whereof hath danger'd many crowns.

As much as waters differeth from the fire,

So much man's profit jar's from what is just.

A free recourse to wrong, doth oft secure

The doubtful seat and plucks down many a foe.

The sword must seldom cease: a sovereign's hand

Is scantly safe, but whiles it smites. Let him

Usurp no crown that likes a guillless life:

Aspiring power and justice seld agree.

He always fears that shames to offer wrong.

Ob nun die 'Misfortunes' vor oder nach dem 'Tamburlain entstanden sind, jedenfalls zeigen sie, wenn auch weder viele trochaeen, noch weibliche ausgänge und caesuren, dennoch 
eine kräftige dramatische form und geschickte verwertung und anwendung des blankverses, zu einer zeit, wo Shakspere vermutlich schon in London war.

An den besprochenen blankversdichtungen lässt sich die formelle entwicklung der kunstpoesie im 16. jahrhundert verfolgen. Surrey, von dem wir ausgiengen, zeigt noch häufige durchbrechung des theoretisch aufzustellenden jambischen rhythmus. Es ist dies einerseits durch das. sich geltendmachen der tonwerte Germanischer wörter und die nachwirkung Altenglischer und Mittelenglischer freiheiten bezüglich des auftactes und der senkungen, andrerseits durch eine gewisse abstumpfung des rhythmischen gefubls unter einfluss des silbenzählenden prinzips der Italiener zu erklären. Die verstösse gegen den jambischen rhythmus schwinden bei Surrey's nachfolgern immer mehr, und es ist bald eine nicht geringe formvollendung zu erkennen, die sich auch im gereimten jambischen fünffussler, wie im sechs- und siebenfüssler zeigt.

Besonders glinstig zeigt sich der blankvers im drama, furr das er eigentlich bestimmt ist, in dem er alle seine freiheit und beweglichkeit entwickelt, den wechsel der pausen und deren uarkierung durch trochaeen, das enjambement und das verteilen eines verses unter mehrere redner. In einzelnen spuren finden sich auch schon reimpaare zu effectvoller bezeichnung des schlusses einer grösseren rede oder eines actes, ferner anwendung der prosa für die reden des clowns. Die erscheinung der weiblichen caesuren, die bei Surrey am häufigsten, in der musterdichtung, dem 'Steele Glas', aber gar nicht vorkommt, erscheint als ein uberbleibsel aus Mittelenglischer zeit bei Surrey; bei den anderen dichtern ist es wol auf eine stufe mit den luberzähligen silben uberhaupt zu stellen. Es ist dies insofern von interesse, als bei Shakspere bekanntlich die weiblichen versausgänge und caesuren in den jugendwerken weit weniger sich finden, als in den späteren.

Vor den ubbrigen dramen der zeit zeichnen die in blankversen sich vor allem durch das gleichmässige beibehalten 
eines und desselben versmasses aus, nur Lyly ist weniger sorgfăltig.

Die kunstmässigen blankverse stehen in bewustem gegensatze zu den mehr volkstümlichen, unregelmåssigen, willktirlich wechselnden rhythmen; in der geschichte der literaturen ist es eine bekannte erscheinung, dass gezierte, verfeinerte dichtung und urwtichsige, derbere art meist schon nebeneinander, aber getrennt vorliegen, ehe sie ein schöpferischer geist vereint.

WIEN.

ARNOLD SCHROEEK. 